\title{
Understanding the importance of primary tropical forest protection as a mitigation strategy
}

\section{Brendan Mackey, et al. [full author details at the end of the article]}

Received: 9 August 2019 / Accepted: 4 September 2019/ Published online: 12 March 2020

(C) The Author(s) 2020

\begin{abstract}
Given the short time-frame to limit global warming, and the current emissions gap, it is critical to prioritise mitigation actions. To date, scant attention has been paid to the mitigation benefits of primary forest protection. We estimated tropical forest ecosystem carbon stocks and flows. The ecosystem carbon stock of primary tropical forests is estimated at 141-159 Pg C (billion tonnes of carbon) which is some $49-53 \%$ of all tropical forest carbon, the living biomass component of which alone is $91-103 \%$ of the remaining carbon budget to limit global warming to below 1.5 degrees above pre-industrial levels. Furthermore, tropical forests have

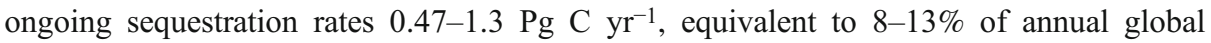
anthropogenic $\mathrm{CO}_{2}$ (carbon dioxide) emissions. We examined three main forest-based strategies used in the land sector-halting deforestation, increasing forest restoration and improving the sustainable management of production forests. The mitigation benefits of primary forest protection are contingent upon how degradation is defined and accounted for, while those from restoration also depend on how restoration is understood and applied. Through proforestation, reduced carbon stocks in secondary forests can regrow to their natural carbon carrying capacity or primary forest state. We evaluated published data from studies comparing logged and unlogged forests. On average, primary forests store around 35\% more carbon. While comparisons are confounded by a range of factors, reported biomass carbon recovery rates were from 40 to $100+$ years. There is a substantive portfolio of forest-based mitigation actions and interventions available to policy and decision-makers, depending on national circumstances, in addition to SFM and plantation focused approaches, that can be grouped into four main strategies: protection; proforestation, reforestation and restoration; reform of guidelines, accounting rules and default values; landscape conservation planning. Given the emissions gap, mitigation strategies that merely reduce the rate of emissions against historic or projected reference levels are insufficient. Mitigation strategies are needed that explicitly avoid emissions where possible as well as enabling ongoing sequestration.
\end{abstract}

Keywords Primary tropical forests $\cdot$ Deforestation $\cdot$ Forest degradation $\cdot$ Proforestation $\cdot$ Carbon stocks $\cdot$ Climate mitigation

Electronic supplementary material The online version of this article (https://doi.org/10.1007/s11027-01909891-4) contains supplementary material, which is available to authorized users. 


\section{Introduction}

Evidence that the planet has already warmed $1{ }^{\circ} \mathrm{C}$ above pre-industrial levels (Millar et al. 2017), and findings that annual global greenhouse gas (GHG) emissions rose to an all-time high in 2018 (Global Carbon Project 2018) underscore recent studies assessing the deep and rapid cuts in greenhouse gas emissions needed to achieve the goals of the United Nations Framework Convention on Climate Change (UNFCCC) Paris Agreement (Millar et al. 2017; Rockström et al. 2017; Rogelj et al. 2015) of limiting the increase in global average temperature to well below $2{ }^{\circ} \mathrm{C}$ above pre-industrial levels and pursuing efforts to limit the temperature increase to no more than $1.5^{\circ} \mathrm{C}$ by the end of the century. The estimated global carbon budget for a $66 \%$ probability of meeting the $1.5{ }^{\circ} \mathrm{C}$ global warming target is around $114 \mathrm{Pg} \mathrm{C}(1 \mathrm{Pg} \mathrm{C}$ is equivalent to 1 billion tonnes of carbon) which represents approximately 11 years of annual emissions at current levels (IPCC 2018). Studies suggest that to achieve this target, global anthropogenic $\mathrm{CO}_{2}$ (carbon dioxide) emissions must reach net zero by about mid-century, and subsequently turning negative so that sequestration rates exceed emissions for decades (Figueres 2017; Millar et al. 2017). However, current commitments in Nationally Determined Contributions (NDC) submitted by governments under the Paris Agreement fall far short of what is needed, thus creating a substantial 'emissions gap' (UN Environment 2018).

Given the very short mitigation time horizon, and the emissions and sequestration gap, it is critical to identify strategies that can help accelerate the transition to net-zero emissions and avoid the severe climate-related impacts of an exceeding $1.5^{\circ} \mathrm{C}$ of global warming. This urgency has prompted greater attention to forest-based mitigation actions given, among other things, the current gross carbon sink in forests recovering from harvests and on abandoned agricultural lands of $4.4 \mathrm{Pg} \mathrm{C} \mathrm{y}^{-1}$ (i.e. per year), and it has been estimated that stopping deforestation and allowing secondary forests to grow would yield cumulative negative emissions between 2016 and 2100 of about $120 \mathrm{PgC}$, globally (Houghton and Nassikas 2018). Particular attention is being paid to tropical countries where deforestation and forest degradation rates are high and in some cases increasing (Baccini et al. 2017; Grassi et al. 2017; Griscom et al. 2017a, b). While a range of forest-based mitigation strategies are recognised, the role of primary forest protection to date has not been explicitly considered in international policy negotiations (Mackey et al. 2015; Watson et al. 2018; Funk et al. 2019).

The aim of this paper is to address this deficit by considering the evidence for the mitigation value of primary tropical forests in relation to other, more commonly promoted forest-based strategies. After clarifying our use of forest definitions, this paper is structured in four parts: we examine the mitigation value of tropical primary forests; we then evaluate the current focus of forest-based mitigation strategies which are based on halting deforestation, increasing forest restoration and improving the sustainable management of production forests; the section that follows addresses the issue of emissions from degradation and selective logging impacts; and we then compare the carbon stocks of primary forests and production forests, along with data on regrowth rate and reduced impact logging. We conclude with recommendations for implementing this approach as a global mitigation strategy, where national circumstances permit.

\section{Forest definitions}

While debate continues over forest definitions (Lund 2014), we refer to 'primary forest' as this is the terminology in use by the Convention on Biological Diversity (CBD), the United 
Nations Food and Agriculture Organization (FAO 2018), the Collaborative Partnership on Forests, the International Union for Conservation of Nature (IUCN), High Forestation Low Deforestation (HFLD) countries and others. As used here, the term encompasses other commonly used descriptors for forests that sit toward one end of the gradient in forest ecological condition that reflects the increasing impact of modern human land use activities including commercial logging, infrastructure development, ranching and mining (Lesslie et al. 1988). Primary forest, therefore, are naturally regenerating forest of native tree species, whose structure, composition and dynamics are dominated by ecological and evolutionary processes. They comprise around 36\% - 14.5 million $\mathrm{km}^{2}$ (square kilometres) — of the global forest estate (Mackey et al. 2015). This definition does not mean however that primary forests are uninhabited by humans. On the contrary, the world's tropical primary forests are the customary homelands of Indigenous Peoples who continue to play a critical role in their protection and conservation management (Garnett et al. 2018; Ricketts et al. 2010). Prior significant human intervention may also have occurred but this was long enough ago to have enabled an ecologically mature forest ecosystem to re-establish (Ellis et al. 2010).

As used here, primary forest encompasses related terms including stable forests (Funk et al. 2019), intact forest (Watson et al. 2018), along with old-growth, long untouched and virgin forest (Buchwald (2005). In tropical forests, the adjective 'primary' also refers to the ecologically mature stage of forest succession in the development of a stand with, typically, fast-growing and shorterlived tree species dominating disturbed sites, followed by slowing growing longer-lived ones (Chazdon et al. 2010). Hinterland forests (Tyukavina et al. 2016) are late-successional tropical forest of at least $100 \mathrm{~km}^{2}$ in area that are either primary forests or have been subject to a modest level of prior disturbance, that retain a canopy dominated by primary successional canopy tree species, and following a period of ecological recovery can be difficult to distinguish from undisturbed canopies, especially by remote sensing. Intact forest landscapes (IFL) are primary forest dominated mosaics with a minimum area of $500 \mathrm{~km}^{2}$ (Potapov et al. 2017).

At the other end of the forest condition gradient are severely degraded forests that require human intervention to enable regrowth. In between are naturally regenerating forests subject to conventional forestry management for commodity production (i.e. wood for timber, pulp and fuel). Based on the notion that homogenous products are cheaper to produce and manipulate, these conventional management practices have typically led to more even-aged and speciespoor stands, and now cover about $30 \%$ the global forest land base (Puettmann et al. 2015). The most intensive form of silviculture results in plantation forest, typically monocultures, comprising trees established through active planting and/or deliberate seeding.

We propose that for our purposes, at the global level, it is sufficient to mirror the approach of FAO (2018) and distinguish between three major categories of forest condition: (i) primary forests as defined above; (ii) production forests used for commercial logging, other industrialscale activities, and are impacted by associated infrastructure, though still reliant on selective natural regeneration; (iii) plantation forests predominantly composed of trees established through planting and/or deliberate seeding of commercial varieties and often using monocultures species exotic to the region.

\section{Primary forest carbon stocks and flows}

Protecting primary forests contributes to climate change mitigation through avoiding emissions from land use and land use change, supporting a stable carbon reservoir, and providing a 
significant carbon sink (Funk et al. 2019). There are, however, no agreed and definitive data sources for defining the tropical forest biome, Mapping forest condition, quantifying extant forest cover, and estimating forest ecosystem carbon stocks. Rather, data are sourced from various sources including government inventories, remotely sensed data, forest plot-based measurements and modelled outputs.

\subsection{Methods}

We updated estimates of forest ecosystem carbon stocks in extant tropical forests using more recently available global data sets.

\subsubsection{Tropical forest regions}

There is no universally accepted global ecoregionalisation for geographically delineating tropical forests. Therefore, we used two widely used classification: the RESOLVE Ecoregions of Dinerstein et al. (2017) and the Global Ecological Zones of FAO (2012) (Supplementary Material Fig. S1).

\subsubsection{Forest cover and condition data}

To map extant tropical forest cover, we used the forest cover data of Hansen et al. (2013) updated to account for forest loss up to 2018. We used two additional datasets to provide the most reliable available pan-tropical data on forest condition. The data from Tyukavina et al. (2016) for so-called 'Hinterland forest'-primary and mature secondary forests of at least $10,000 \mathrm{ha}^{-1}$ extent — and Turubanova et al. (2018) maps natural forest that includes areas that have experienced partial canopy loss at the $30-\mathrm{m}$ mapped spatial resolution. For this paper, we used 'Hinterland tropical forest' as the most accurate approximation of primary tropical forest extent, while the mapping of Turubanova et al. (2018) was used to represent forests in a more degraded condition called 'Mature \& partially degraded tropical forest'. The residual forest area-i.e. the area of Hansen et al. (2013) forest that fell outside the Hinterland and Turubanova et al. (2018) forest-was assumed to be 'Degraded \& regrowth tropical forest' (Fig. 1).

\subsubsection{Forest carbon data}

Estimates of forest carbon (C) were calculated by multiplying the area of forest in each of the three ecological conditions by available data on the density of forest ecosystem $\mathrm{C}$ in each of major pools: (i) above-ground living biomass (AGLB) (i.e. tree stems, branches and roots); (ii) below-ground living biomass (BGLB) (tree roots); (iii) above-ground dead biomass (AGBD) (including coarse woody debris on the forest floor); (iv) soil. The carbon fraction of biomass was assumed to be $0.5(50 \%)$, an appropriate default value where no local values are available and when being applied across a wide range of forest types (Smith et al. 2013; Penman et al. 2003):

- Two available global modelled estimates of AGLB were used, (Santoro et al. 2018; Avitabile et al. 2016); 


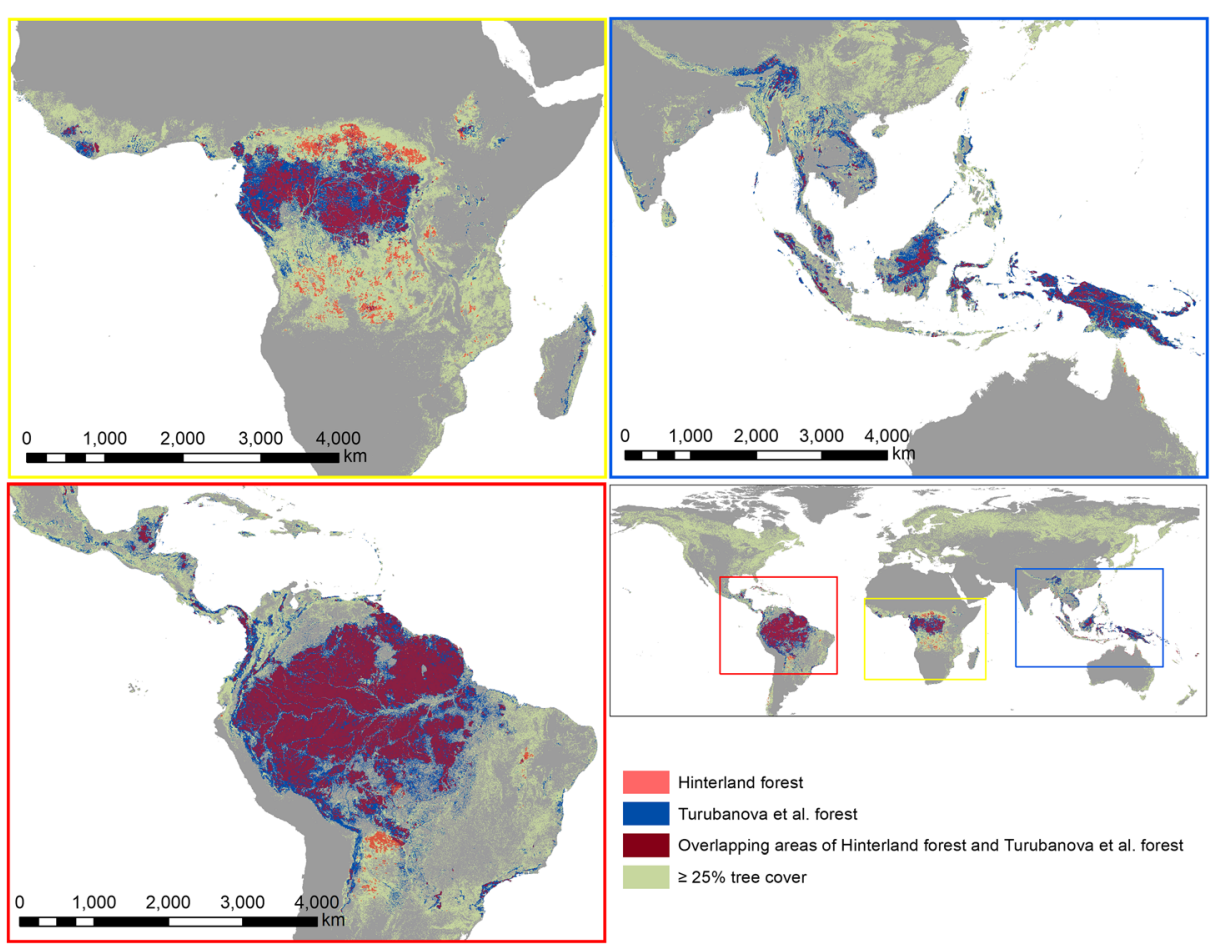

Fig. 1 Tropical forest cover: Hinterland forest from Tyukavina et al. (2016) was used as best approximation of 'Primary forest'; the mapping of Turubanova et al. (2018) was used to represent forests in a more degraded condition called 'Mature \& partially degraded tropical forest'; the remaining forest as defined by $>25 \%$ canopy cover from Hansen et al. (2013) updated for loss to 2018 was interpreted as 'Degraded \& regrowth tropical forest' (further details in Supplementary Material)

- Spatially distributed estimates of BGLB were not available. Therefore, BGLB was calculated as a fraction of AGLB using the mean root-shoot ratio derived from Waring and Powers (2017);

- Spatially distributed estimates were also not available for AGDB. Therefore, we used an expansion factor from Yang et al. (2010); and

- Spatially distributed estimates of soil C were obtained from FAO and ITPS (2017).

Further details on methods and data are provided in Supplementary Material.

\subsection{Results}

Extant tropical forest ecosystem carbon stocks were calculated to be in the range 306-324 Pg $\mathrm{C}$, with living biomass carbon of 204-221 Pg C. The total ecosystem carbon in primary forests ranged 141-159 Pg C, with living biomass carbon of 104-118 Pg C, depending on which of the two geographic definitions of the tropical forest biome (Dinerstein et al. 2017; FAO 2012), and which of the two data sources for above-ground biomass carbon (Avitabile et al. 2016; Santoro et al. (2018), were used (Table 1, Fig. 2).

The results are consistent with other global estimates of tropical forests and carbon stocks. We estimated the total area of tropical forest cover to be $11,219,047-13,393,614 \mathrm{~km}^{2}$ with primary tropical forest covering 5,128,046-5,479,329 $\mathrm{km}^{2}$ (Table 1). Based on FAO (2015) 
data gathered through formal government reporting, there is an estimated $17,133,240 \mathrm{~km}^{2}$ of tropical forest; of which, $5,410,000 \mathrm{~km}^{2}(32 \%)$ is the primary tropical forest (Morales-Hidalgo et al. 2015; Keenan et al. 2015). Reasons for the range in estimates include differences in the year of reporting, the definition of primary forest adapted and the geographic area delineated for the study, along with different data sources and spatial modelling approaches. The

Table 1 Indicative estimates of extant carbon stocks of tropical primary forests

\begin{tabular}{|c|c|c|c|c|c|c|c|c|}
\hline & \multirow[t]{2}{*}{ I } & \multirow[t]{2}{*}{ II } & \multicolumn{2}{|c|}{$\begin{array}{l}\text { Hinterland tropical } \\
\text { forest }\end{array}$} & \multicolumn{2}{|c|}{$\begin{array}{l}\text { Mature and partially } \\
\text { degraded tropical } \\
\text { forest }\end{array}$} & \multicolumn{2}{|c|}{$\begin{array}{l}\text { Degraded and } \\
\text { regrowth tropical } \\
\text { forest }\end{array}$} \\
\hline & & & $\mathrm{I}$ & II & $\mathrm{I}$ & II & I & II \\
\hline \multicolumn{9}{|c|}{ Above-ground living biomass carbon $(\mathrm{Pg} \mathrm{C})$} \\
\hline $\begin{array}{l}\text { Avitabile } \\
\text { et al. } \\
(2016)\end{array}$ & 150 & 128.1 & 79.7 & 74.1 & 128.2 & 117 & 22 & 11 \\
\hline $\begin{array}{l}\text { Santoro } \\
\text { et al. } \\
(2018)\end{array}$ & 132.2 & 117.2 & 70.4 & 65.8 & 112.1 & 103.3 & 20 & 14 \\
\hline $\begin{array}{l}\text { Root } \\
\text { biomass } \\
\text { carbon }\end{array}$ & 71.3 & & 38 & & & & 33 & 33 \\
\hline \multicolumn{9}{|c|}{ Living biomass carbon $(\mathrm{Pg} \mathrm{C})$} \\
\hline $\begin{array}{l}\text { Avitabile } \\
\text { et al. } \\
(2016)\end{array}$ & 221.3 & 199.4 & 117.7 & 112.1 & 166.2 & 155 & 55 & 44 \\
\hline $\begin{array}{l}\text { Santoro } \\
\text { et al. } \\
(2018)\end{array}$ & 203.5 & 188.5 & 108.4 & 103.8 & 150.1 & 141.3 & 53 & 47 \\
\hline AGDBC & & 13.2 & 7 & & & & 6 & 6 \\
\hline $\begin{array}{l}\text { Soil carbon } \\
(\mathrm{Pg} \mathrm{C})\end{array}$ & 89.1 & 69.5 & 34.1 & 29.9 & 64.8 & 54.5 & 24 & 15 \\
\hline \multicolumn{9}{|c|}{ Total ecosystem carbon $(\mathrm{Pg} \mathrm{C})$} \\
\hline $\begin{array}{l}\text { Avitabile } \\
\text { et al. } \\
(2016)\end{array}$ & 323.6 & 282.1 & 158.8 & 149.1 & 238.0 & 216.5 & 86 & 66 \\
\hline $\begin{array}{l}\text { Santoro } \\
\text { et al. } \\
(2018)\end{array}$ & 305.8 & 271.2 & 149.4 & 140.7 & 221.9 & 202.8 & 84 & 68 \\
\hline Area $\left(\mathrm{km}^{2}\right)$ & $13,393,614$ & $11,219,047$ & $5,479,329$ & $5,128,046$ & $9,227,315$ & $8,379,957$ & $4,166,299$ & $2,839,090$ \\
\hline (A) & & & 41 & 46 & 69 & 75 & 31 & 25 \\
\hline (B) & & & 49 & 53 & 74 & 77 & 26 & 23 \\
\hline
\end{tabular}

Two sources were used to map the boundary of the tropical forest biome: (I) tropical and subtropical moist broad leaf forests from Dinerstein et al. (2017); and (II) tropical forest cover from FAO (2012) global ecological zones; Hinterland tropical forest data from Tyukavina et al. (2016); Mature and partially degraded tropical forest data from Turubanova et al. (2018); Degraded \& regrowth tropical forest was calculated as the residual of Extant tropical forests that was outside Hinterland or Mature and partially degraded forests; Extant tropical forest was mapped based on tree cover $\geq 25 \%$ from Hansen et al. (2013). Two sources of above-ground living biomass carbon were used: Avitabile et al. (2016) and Santoro et al. (2018); Root biomass carbon (RBC) was calculated as a fraction of above-ground living biomass carbon (AGLBC) using the mean root-shoot ratio of 132 observations collected in native, unmanaged forests by Waring and Powers (2017; Living biomass carbon is the sum of AGLBC and RBC; AGDBC (above-ground dead biomass carbon) used a mid-range expansion factor for oldgrowth tropical forest (Yang et al. 2010); Soil carbon data from FAO and ITPS (2017). Row (A) fraction (\%) of tropical forest area (\%); row (B) fraction (\%) of Avitabile et al. (2016) tropical forest ecosystem carbon. Further details in Supplementary Material 


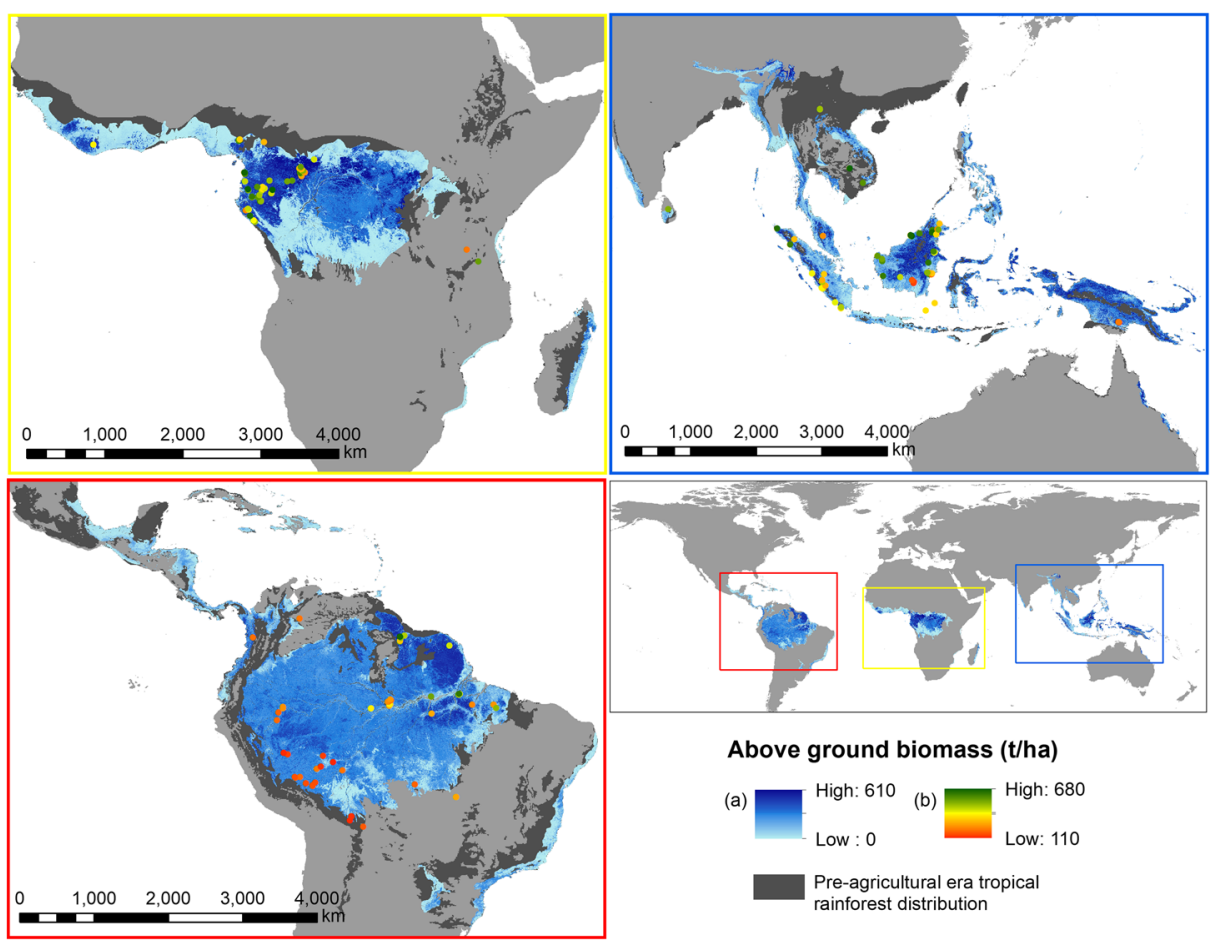

Fig. 2 Global spatial estimate of pan-tropical above-ground biomass $\left(\mathrm{t} \mathrm{ha}^{-1}\right)$ from Avitabile et al. (2016) within the FAO (2012) tropical rainforest biome. The aboveground forest biomass $\left(\mathrm{t} \mathrm{ha}^{-1}\right)$ measured at sites or estimated from forest inventory that represents primary forest are mapped as coloured circles. Sources for the site data are provided in Supplementary Material Table S1 and a comparison of the modelled values at these sites in Supplementary Material Fig. S2

difference in the estimated total areas of tropical forest is possibly because we restricted our analysis to within two specific bioregions and areas with $\geq 25 \%$ tree cover. The estimates of areas of primary forest cover are more comparable.

We calculated that primary tropical forests store $49-53 \%$ of all tropical forest carbon with another $\sim 25 \%$ in the forest that has been subject to some land use disturbance, and a further $25 \%$ in more severely degraded forest (Table 1). The mitigation significance of the living biomass carbon in primary tropical forests $(104-118 \mathrm{Pg} \mathrm{C})$ is highlighted by the fact that this is 91-103\% of the remaining carbon budget of $\sim 114 \mathrm{Pg} \mathrm{C}$ for a $66 \%$ probability of limiting global warming to $1.5^{\circ} \mathrm{C}$ above pre-industrial levels (IPCC 2018). As deforestation and degradation of primary tropical forests continue at significant rates (Turubanova et al. 2018; Curtis et al. 2018; Asner et al. 2010), this ongoing source of emissions is therefore a significant threat to stabilising atmospheric $\mathrm{CO}_{2}$ concentrations even if fossil fuel emissions are eliminated.

While the above-ground living biomass carbon of primary tropical forests and all tropical forests is substantial, emissions from all forest ecosystem components - below-ground living biomass, above- and below-ground dead biomass and soil carbon-should be considered in assessing the mitigation value of forest management actions. However, as below-ground biomass and soil carbon are difficult to measure, and above-ground dead biomass is of no commercial value, most greenhouse gas inventories and forest carbon accounts only record 
changes in the stocks and flows of above-ground living biomass carbon. As above-ground living biomass is at best only $50 \%$ of total forest ecosystem carbon (Table 1; Grace et al. 2014; Keith et al. 2009; Navarrete-Segueda et al. 2018), emissions from deforestation and degradation are being potentially significantly underestimated and the mitigation benefits of primary forest protection undervalued.

Contrary to the widely held view that carbon stocks in primary forests reach a fixed equilibrium amount (Xu et al. 2017), these stocks appear to be increasing monotonically throughout the tropics at a rate of 0.47-1.3 $\mathrm{PgC} \mathrm{yr}^{-1}$ (Grace et al. 2014; Lewis et al. 2009; Mitchard 2018; Pan et al. 2011), equivalent to 5-13\% of annual global anthropogenic emissions (IPCC 2018). The rate of sequestration in primary tropical forests is estimated to be approximately equivalent to the emissions resulting from deforestation, based on comparisons of atmospheric inverse models (Gaubert et al. 2019). This ongoing sink can be explained by several factors:

- Old-growth trees in tropical forests maintain high rates of carbon accumulation at later stages of their lifetime, with 70-80\% accumulated in the second half of life when trees are 70 years or older (Köhl et al. 2017);

- Carbon storage in primary forests will continue to increase when canopies are dominated by tree species with greater tree longevity and hence biomass residency time (Castanho et al. 2016; Körner 2017); and

- The $\mathrm{CO}_{2}$ fertilisation effect, that is, enhanced biomass growth due to elevated $\mathrm{CO}_{2}$ levels (Donohue et al. 2013; Nemani et al. 2003; Pan et al. 2011).

While the principle mitigation value of primary forest ecosystems resides in their accumulated carbon stocks (Mackey et al. 2013), given the urgent need for short-term action to achieve the goals of the Paris Agreement (UN Environment 2018; IPCC 2018), primary tropical forests are a potentially significant sink for near-term additional carbon dioxide removal.

\section{Current focus of forest mitigation strategies}

Forest-based mitigation approaches as reflected in Nationally Determined Contributions (NDC) of the Paris Agreement, in multilateral instruments (for example, the United Nations Sustainable Development Goals, the United Nations strategy for forests 2017-2030, Reduced Emissions from Deforestation and Forest Degradation or REDD+), and in the scientific literature, have focused mainly on three strategies: (1) reducing emissions by reducing the rate of deforestation from land conversions mainly to agriculture, (2) increasing sequestration through forest restoration and (3) sustainable forest management based on alternative silvicultural practices that reduce emissions compared with conventional forestry management.

\subsection{Deforestation}

Reducing tropical deforestation has been a long-standing international policy priority and the United Nations Sustainable Development Goals call for halting deforestation by 2020. From a mitigation standpoint, deforestation is a major problem as it causes 0.8-0.9 Pg C of net emissions per year much of which occurs in the tropics (Grace et al. 2014; Harris et al. 2012; Houghton 2013; Pendrill et al. 2019), about 8\% of annual global anthropogenic 
emissions (IPCC 2018). Despite the attention it receives, deforestation continues, particularly in the tropics. According to the UN Food and Agriculture Organization data, 5.5 million ha of tropical forests was cleared annually between 1990 and 2015, and other estimates suggest that losses may be much higher and accelerating (Keenan et al. 2015). A major driver of deforestation is for agricultural expansion and tree plantations, with about a third of the carbon emissions embodied in international trade (Pendrill et al. 2019). Avoiding deforestation must therefore continue to be a mitigation policy focus.

Deforestation policies, however, may be ineffective in protecting forests if a definition of 'forest' is used that is based on land use change or inappropriate biophysical thresholds. Under the Kyoto Protocol, an area is a forest, if it is at least $0.05-1.0$ ha, has a tree crown cover of more than $10 \%$ and the potential to reach at least $2 \mathrm{~m}$ height (UNFCCC 2002). Under this definition, a primary forest can be intensely logged so that all canopy trees are removed and not deemed to be deforested so long as the intention is to keep logging it in the future or if the remaining understory vegetation meets the minimum canopy height and cover thresholds. These definitions set false equivalences between an area of primary forest and, for example, a replacement tree plantation.

\subsection{Forest restoration}

Forest restoration, which includes reforestation and afforestation, is a well-supported mitigation strategy. The Bonn Challenge, for example, is a global effort to bring 150 million ha ${ }^{-1}$ of the world's deforested and degraded land into restoration by 2020, and 350 million ha ${ }^{-1}$ by 2030 (IUCN 2011). The mitigation benefits of forest restoration also depend on how it is defined. Forest restoration can refer to restoring the agroforestry productivity of degraded landscapes rather than ecological forest restoration (Lewis et al. 2019). There are substantial potential mitigation benefits from ecological restoration, however, from enabling the natural regeneration of forests that have been cleared or allowing disturbed forests to regrow. The update of carbon by secondary tropical forest regrowth is estimated at $0.8 \mathrm{PgC}-1.6 \mathrm{PgC} \mathrm{yr}^{-1}$ (Grace et al. 2014; Erb et al. 2017).

Conventional forestry management maintains forests in the equivalent of a young, secondary regrowth phase. The reduced carbon stocks in these secondary forests mean that they have the potential to sequester additional carbon at an accelerating rate for many decades or longer if allowed to grow to ecological maturity, i.e. their primary forest state, a management principle known as proforestation (Moomaw et al. 2019; Mackey et al. 2008; Lewis et al. 2019). This sequestration potential is the difference between the current carbon stock in a production forest and the natural carbon carrying capacity if allowed to recover fully without further logging (Keith et al. 2010).

While the rate of growth following afforestation is similar to reforestation, and slower than proforestation, it requires large amounts of land that are unlikely to be converted from other uses to forests. Proforestation can sequester more carbon per hectare than a planted forest growing over the same time period because the trees in a natural forest are established, larger, on the steepest part of their growth curve and consist of the native mix of species (Moomaw et al. 2019). The advantage of a native mix of species, rather than monocultures or plantations with a few species, was demonstrated by the finding that about a quarter of the variation in carbon stocks of different subtropical forest plots was explained by tree species diversity (Liu et al. 2018). However, this does not necessarily mean there is a relation between carbon stocks and biodiversity across different forest types (Ferreira et al. 2018). 


\subsection{Sustainable forest management}

Mitigation strategies based on deforestation and restoration, even when defined appropriately, still leaves open the prospect of emissions from forest degradation (Funk et al. 2019; Pearson et al. 2017). Forest management for commodity production results in degradation because the land use activities disturb forests and reduce forest ecosystem carbon stocks, including logging, fuelwood extraction and sub-canopy grazing and cultivation, fragmentation from roading and biodiversity loss that impacts on ecosystem processes.

Degradation is often overlooked because space-borne instruments cannot readily detect the change in forest condition and the partial removal of trees does not constitute deforestation. However, emissions from degradation are highly significant globally, and some regions even exceed those from deforestation (Asner et al. 2005; Huang and Asner 2010; Pearson et al. 2017). Erb et al. (2017) found that $42-47 \%$ of emissions from vegetation biomass globally were due to degradation rather than clearing of vegetation. Baccini et al. (2017) suggested that degradation emissions exceeded those from deforestation globally, with 69\% (1.8 $\mathrm{Pg} \mathrm{CO}$; note that 1 unit of $\mathrm{CO}_{2}$ is equivalent to 3.67 units of C) of these from tropical forests. Ellis et al. (2019) estimated emissions from degradation due to selective logging in tropical forests at 0.8 $1.9 \mathrm{Pg} \mathrm{CO}_{2} \mathrm{yr}^{-1}$.

Degradation is recognised in the United Nations Collaborative Programme on Reducing Emissions from Deforestation and Forest Degradation in Developing Countries (REDD+). However, the emphasis in REDD+ is on reducing rather than avoiding emissions outright, and it is a voluntary approach for developing not developed countries. The main approach advocated has been to reduce emissions by changing conventional forestry management. Article 5 of the Paris Agreement encourages Parties to implement 'sustainable management of forests', more commonly referred to as Sustainable Forest Management (SFM) that results in Reduced Impact Logging (RIL) compared with conventional silvicultural practices.

The mitigation benefits of SFM/RIL, however, should be assessed relative to those derived from avoiding emissions through primary forest protection and the sequestration from proforestation. A critical evaluation is therefore needed of the emissions arising from the commercial logging of primary forests and the impacts on forest ecosystem carbon stocks.

\section{Selective logging impacts}

Selective logging is the main kind of tree harvesting in tropical forests and encompasses a range of intensities of timber extraction (from $<5$ to $200 \mathrm{~m}^{3} \mathrm{ha}^{-1}$; i.e. less than 5 to 200 cubic metres per hectare), logging cycles (typically 30 years), and logging practices, with varying degrees of ground disturbance (Chaudhary et al. 2016; Günter et al. 2011; Putz et al. 2000). In tropical forests, conventional selective logging removes the largest, highest quality trees above a threshold stem diameter within a forest stand while aiming to leave the remaining trees standing (Gatti et al. 2015). Selective logging has impacted about 5 million $\mathrm{km}^{2}$ of tropical forest, of this area about 4.7 million $\mathrm{km}^{2}$ are managed as production forests, representing over a quarter of all tropical forests (Sasaki et al. 2016).

The difference in biomass carbon stocks between primary and production tropical forests depends on the intensity and methods of selective logging: the more trees cut per hectare, the shorter the logging cycles and the greater the collateral damage, then the greater the reduction in the forest carbon stock (Burivalova et al. 2014; Bustamente et al. 2016; Martin et al. 2015; 
Rutishauser et al. 2015). Both direct and indirect impacts of selective logging on tropical forest carbon stocks in biomass and soil must be considered. These impacts are mitigated to a limited extent by carbon storage in wood products derived from the logged forest, although only a small proportion of these wood products (about 10\%) are long-lived (that is, longer than 90 years) (Harmon 2019; Keith et al. 2015; Pearson et al. 2014; Winjum et al. 1998). As such, the benefit is transient.

\subsection{Direct impacts}

The most important impact of selective logging on carbon stocks is the removal of the large, valuable, mature hardwood trees. These contain the most timber, but also a remarkably high proportion of the above-ground biomass carbon in primary tropical forest, even though they occur at low densities per hectare (Körner 2017; Stephenson et al. 2014). For example, Slik et al. (2013) found that in South America, Southeast Asia and Africa, large trees over $70 \mathrm{~cm}$ diameter at breast height (d.b.h.), only represented 1.5, 2.4 and 3.8\% respectively of stems larger than $10 \mathrm{~cm}$ d.b.h., but nonetheless stored 25, 39 and $45 \%$ of above-ground biomass of all trees. Similarly, Sist et al. (2014) found that large trees (over $60 \mathrm{~cm}$ d.b.h.) represented only $9.3 \%$ of tree density but contained almost half the above-ground biomass in a forest stand. Lutz et al. (2018) also found that globally half of all above-ground living biomass was in the largest $1 \%$ diameter trees.

Not only do these large trees continue to sequester carbon throughout their lives (Stephenson et al. 2014), often living > 300 years and sometimes much longer (Vieira et al. 2005), but there is also evidence that they store increasing amounts as they age (Stephenson et al. 2014). For example, Köhl et al. (2017) found that trees in primary forest in Suriname accumulated 39-50\% of their total carbon stock in the last quarter of their lives. Thus, removing these trees has a disproportionate effect on forest carbon storage, which can persist for decades (Gatti et al. 2015). These large trees belong to a small proportion of hyperdominant species, for example, half of the carbon stock in Amazonian tropical forests is contained in about $1 \%$ of the species that are characterised by large sizes and high wood density (Fauset et al. 2015, b).

Selective logging also causes significant collateral damage to the surrounding ecosystem. When a large tree is felled, it damages or crushes other trees on its way down. Damaged trees may die immediately or many years after logging, with tree mortality estimated to continue for at least 10 years after logging (Huang and Asner 2010; Schulze and Zweede 2006). Treefall in logged areas also occurs when canopy openings make the forest susceptible to wind, and root damage is caused by soil destabilisation along skid trails (Schulze and Zweede 2006). Trees are felled to build logging roads and skid trails and for the construction of logging infrastructure, and these clearings also lead to edge effects, such as increased sunlight, wind disturbance and increased incidence of fire (Bryan et al. 2013; Ellis et al. 2019). Tyukavina et al. (2016) found that tree mortality resulting from edge effects could occur up to $1 \mathrm{~km}$ into the forest, and impacts could be found up to $2 \mathrm{~km}$ from an edge. Brinck et al. (2017) suggested that edge effects globally resulted in losses of $0.34 \mathrm{Pg} \mathrm{C} \mathrm{yr}^{-1}$, which would increase estimates of global emissions from degradation substantially. Below-ground biomass carbon is typically ignored in studies reviewing selective logging impacts (Mokany et al. 2006). Logging forests also depletes soil carbon due to erosion, compaction, increased rates of heterotrophic respiration and reduced inputs from biomass turnover, and soil carbon is re-accumulated very slowly (Hamburg et al. 2019).

Selective logging also changes the structure and composition of the forest. By opening the canopy and allowing light to enter the forest, selective logging allows invasive weeds and 
lianas to spread (Gatti et al. 2015). This inhibits growth of existing trees, causes tree mortality and slows regeneration of hardwood species and ecological succession. van der Heijden et al. (2015) found that lianas reduced net above-ground carbon uptake (growth and recruitment minus mortality) by $\sim 76 \%$ per year, mostly by reducing tree growth. Berenguer et al. (2018) found that lianas hamper the recovery of tree species with high levels of wood density postlogging, thus affecting the accumulation of forest carbon stocks.

\subsection{Indirect impacts}

One of the key indirect impacts of logging in tropical forests is the increased incidence of fire. As a result of canopy openings and fragmentation from logging roads and skid trails, logged forests are drier and have higher daytime shortwave radiation, temperature and wind speed, and their capacity to buffer and stabilise microclimates is reduced (Uhl and Kauffman 1990). They also have more fuel in the form of dead trees, woody debris and slash. Hence, they are much more fire-prone, a problem compounded by climate change and increasing droughts (Cochrane 2003; Huang and Asner 2010; Matricardi et al. 2010; Sasaki et al. 2016; Tyukavina et al. 2016; Giardina et al. 2018).

Logging roads create access to previously remote forest areas, increasing hunting pressure (Laurance et al. 2014). Defaunation through hunting results in the loss of seed dispersers, which in turn effects on forest structure and biodiversity of the forest. Uncontrolled hunting to supply bushmeat markets using logging roads has had large negative consequences for biodiversity and forest productivity throughout the tropics (Benitez-López et al. 2019). Logging roads facilitate colonisation and additional development. Laurance et al. (2014) estimate that at least 25 million $\mathrm{km}$ of new roads will be built by 2050 , a $60 \%$ increase in the global extent of roads since 2010 , $90 \%$ of which would occur in developing countries. Many studies note the serious and increasing problem of forest fragmentation globally from road building, a problem that is likely to worsen (Haddad et al. 2015; Ibisch et al. 2017; Taubert et al. 2018).

Logged forests are far more likely to be converted to agriculture (Asner et al. 2006; Barber et al. 2014; Boakes et al. 2010; Gibbs et al. 2010; Laurance and Balmford 2013; Laurance et al. 2014; Shearman et al. 2012) because of the access created by logging roads and the decrease in land value once timber is removed. Deforestation is not necessarily immediate, that is within 3 years, but often happens soon thereafter. One study found that $95 \%$ of the deforestation in the Amazon happens within $5.5 \mathrm{~km}$ of a road or navigable river (Barber et al. 2014). Poor governance in forest sectors in the tropics also remains a major concern. Illegal logging, which is up to $87 \%$ of all tropical logging, has attracted attention in recent years because the problem is so pervasive (Hoare 2015; Lawson 2014; Lawson and MacFaul 2010). In many cases, legal concessions enable illegal logging and other illegal development activities to spread (Finer et al. 2014).

\section{Comparing primary forest, production forest and plantation carbon stocks}

Primary tropical forests store on average $\sim 250 \mathrm{t} \mathrm{C} \mathrm{ha}^{-1}$ total above-ground biomass carbon stock, with $\sim 175 \mathrm{t} \mathrm{C} \mathrm{ha}^{-1}$ being above-ground living biomass and the remainder dead biomass (Keith et al. 2009; Pan et al. 2011). We reviewed published studies which revealed that tropical production forests store on average $35 \%$ less carbon than primary tropical forests of the same type (Table 2 and Supplementary Material Table S1) due to the direct and indirect logging impacts. The locations of study sites with their reported estimates of above-ground biomass 
density in primary forest $(n=35)$ are shown in Fig. 1 . The reported reduction in carbon stocks of logged forests range from 2.5 to $91 \%$ (Table 2 and Supplementary Information Table S1). Environmental, biological, management and historical factors influence this carbon stock loss over logging rotations (Supplementary Information Fig. S3).

While the evidence is clear that logging primary forests or converting them to plantations depletes their ecosystem carbon stocks, the counter-argument is that natural forest regrowth and carbon recovery, together with alternative silvicultural practices such as RIL, can enable commercial harvesting logging to be sustainable and are sufficient to ensure impacts are minimised, even if the amount of carbon stored and the size of the annual carbon sink is reduced from that of a primary forest. Therefore, it was also necessary to consider the published data for rates of post-logging forest regrowth. We found that a range of postlogging tropical tree biomass regrowth times has been reported from 45 to $100+$ years (Blanc et al. 2009; Huang and Asner 2010; Pinard and Cropper (2000) (Table 2, Supplementary Material Table S1).

The range in reported reductions and regrowth can be largely explained by the variation in the factors considered by the studies including the following:

- Logging intensity and rotation period - the greater the number of trees, the shorter the time between harvests, and the greater the volume of biomass removed, the more forest carbon stocks are reduced;

- Scope of analyses - whether both indirect and direct impacts are considered including collateral damage — of harvesting operations on non-target trees and other forest biomass carbon pools including soil (Blanc et al. 2009; Chaudhary et al. 2016);

- Source of calibration data - often biomass allometric equations are used based on young stands $(<40$ years) which underestimate carbon stocks of old trees in primary forests (Keith et al. 2015); and

- Wood density estimates - the difference between tree species of the same size can be more than twofold (Berenguer 2018).

Pearson et al. (2014), for example, estimated logged forests only had 3-15\% less carbon, but noted their study only assessed tree mortality for 4 years after logging, only counted trees that had been uprooted or snapped as the direct result of logging, did not measure tree mortality from partially damaged trees that were still standing, and did not include trees that were cut down but left behind because they were unsuitable for processing. They also did not consider tree mortality from sources not related to tree fall while logging, such as windthrow or edge effects. Where more comprehensive sampling techniques comparing logged and unlogged forests are employed, differences are typically $30 \%$ or more (for example, Blanc et al. 2009; Bryan et al. 2010). Evaluating results from studies of carbon stock loss due to logging requires the assessment of the comprehensiveness of the data, the reliability of its estimation, and comparability of data across studies (Table 3, Supplementary Material Figure S1).

From a climate mitigation perspective, the key factor is the time that a unit of biomass carbon is resident in a forest ecosystem stock and thus kept out of the atmosphere. The sequestration of carbon into short-lived pioneer species is released back into the atmosphere in a few decades (Pinard and Cooper 2000). By contrast, the big old trees that dominate tropical primary forests provide longer and more stable carbon residency times (Körner 2017; Stephenson et al. 2014), which means that primary tropical forests can maintain larger carbon stocks over centuries (Mackey et al. 2013). Tree density and age cohorts are also an important 
Table 2 Synthesis of published biomass carbon stock densities and accumulation rates in tropical forests, categorised by forest type and continent

\begin{tabular}{|c|c|c|c|c|c|c|c|c|}
\hline \multirow[t]{2}{*}{ Location } & \multicolumn{5}{|c|}{$\begin{array}{l}\text { Above-ground living biomass carbon stock density ( } \mathrm{tC} \\
\mathrm{ha}^{-1} \text { ) }\end{array}$} & \multicolumn{2}{|c|}{$\begin{array}{l}\mathrm{C} \text { accumulation rate } \mathrm{tC} \\
\left.\mathrm{ha}^{-1} \mathrm{yr}^{-1}\right)\end{array}$} & \multirow{2}{*}{$\begin{array}{l}\text { Time for } \\
\text { recovery } \\
\text { (years) }\end{array}$} \\
\hline & $\begin{array}{l}\text { Primary } \\
\text { forest }\end{array}$ & $\begin{array}{l}\text { Current } \\
\text { condition }\end{array}$ & $\begin{array}{l}\text { Selectively } \\
\text { logged }\end{array}$ & $\begin{array}{l}\text { Net } \\
\text { emissions }\end{array}$ & $\begin{array}{l}\% \\
\text { reduction }\end{array}$ & $\begin{array}{l}\text { Primary } \\
\text { forest }\end{array}$ & $\begin{array}{l}\text { Regrowth } \\
\text { forest }\end{array}$ & \\
\hline \multicolumn{9}{|l|}{ Pan-tropical } \\
\hline $\begin{array}{l}\text { All } \\
\text { tropical } \\
\text { forest }\end{array}$ & $\begin{array}{l}190 \\
(80-271)\end{array}$ & $\begin{array}{l}139 \\
(65-263)\end{array}$ & 97 & & $\begin{array}{l}34 \\
(3-91)\end{array}$ & 0.49 & 0.39 & \\
\hline $\begin{array}{l}\text { Tropical } \\
\text { rainfore- } \\
\text { st }\end{array}$ & 146 & & & & & 1.4 & & \\
\hline $\begin{array}{l}\text { Tropical } \\
\text { moist }\end{array}$ & 112 & & & & & 0.94 & & \\
\hline $\begin{array}{l}\text { Tropical } \\
\text { dry }\end{array}$ & 73 & & & & & 0.74 & & \\
\hline \multicolumn{9}{|c|}{ South America } \\
\hline $\begin{array}{l}\text { All } \\
\text { tropical } \\
\text { forest }\end{array}$ & $\begin{array}{l}156 \\
(113-256)\end{array}$ & $\begin{array}{l}102 \\
(92-118)\end{array}$ & $\begin{array}{l}116 \\
(36-212)\end{array}$ & $\begin{array}{l}42 \\
(6-85)\end{array}$ & $\begin{array}{l}26 \\
(2.5-70)\end{array}$ & $\begin{array}{l}0.84 \\
(0.78-0.89)\end{array}$ & $\begin{array}{l}1.6 \\
(0.5-4.4)\end{array}$ & $\begin{array}{l}>55 \\
(20-> \\
100)\end{array}$ \\
\hline $\begin{array}{l}\text { Tropical } \\
\text { rainfore- } \\
\text { st }\end{array}$ & $\begin{array}{l}175 \\
(149-189)\end{array}$ & & $\begin{array}{l}154 \\
(141-167)\end{array}$ & 48 & $\begin{array}{l}19 \\
(10-25)\end{array}$ & & 1.3 & 51 \\
\hline $\begin{array}{l}\text { Tropical } \\
\text { moist }\end{array}$ & 144 & & & & & & & \\
\hline \multicolumn{9}{|l|}{ SE Asia } \\
\hline $\begin{array}{l}\text { All } \\
\text { tropical } \\
\text { forest }\end{array}$ & $\begin{array}{l}265 \\
\quad(225-- \\
305)\end{array}$ & $\begin{array}{l}121 \\
\quad(113-4- \\
11)\end{array}$ & & & & & & \\
\hline $\begin{array}{l}\text { Tropical } \\
\text { rainfore- } \\
\text { st }\end{array}$ & $\begin{array}{l}170 \\
(80-274)\end{array}$ & & $\begin{array}{l}103 \\
(64-228)\end{array}$ & $\begin{array}{l}81 \\
(41-108)\end{array}$ & $\begin{array}{l}44 \\
(15-56)\end{array}$ & 0.28 & 1.4 & \\
\hline $\begin{array}{l}\text { Tropical } \\
\text { moist }\end{array}$ & $\begin{array}{l}194 \\
(155-234)\end{array}$ & & $\begin{array}{l}116 \\
(97-135)\end{array}$ & & 44 & & & \\
\hline $\begin{array}{l}\text { Tropical } \\
\text { dry }\end{array}$ & $\begin{array}{l}48 \\
(20-70)\end{array}$ & & & & & & & \\
\hline $\begin{array}{l}\text { Tropical } \\
\text { montane }\end{array}$ & 130 & & 90 & & 30 & & & \\
\hline \multicolumn{9}{|l|}{ Africa } \\
\hline $\begin{array}{l}\text { All } \\
\text { tropical } \\
\text { forest }\end{array}$ & $\begin{array}{l}180 \\
(125-229)\end{array}$ & $\begin{array}{l}114 \\
(85-143)\end{array}$ & 222 & 7 & 3.1 & & & \\
\hline $\begin{array}{l}\text { Tropical } \\
\text { moist }\end{array}$ & 209 & & & & & & & \\
\hline
\end{tabular}

(For complete database and references, see Supplementary Material). Classification of forest condition as 'Primary Forest', 'Current Condition' and 'Selectively Logged' reflects descriptions for each study, with 'Current Condition' including forests of varying disturbance history and age structure. The mean and range of values are given based on all reported studies in the category. Data are provided for above-ground live biomass as this was the most commonly reported biomass component. An above- to below-ground ratio of 0.24 (IPCC 2006 Table 4.4) was used where data required converting from total biomass. Classification of forest types follows that used by the IPCC (2006) which in turn are derived from global ecological zones based on observed climate and vegetation patterns (FAO 2012). This classification is consistent with the Holdridge life zones, except that the FAO Rainforest includes both Holdridge Wet Forest and Rainforest 
consideration as a few older trees have larger, more stable and resilient carbon stocks compared with many young trees that are shorter-lived pioneer and secondary growth species (Huang and Asner 2010; Pinard and Cropper 2000).

The biomass carbon stocks of plantation forests depend on the species planted, their purpose (e.g. for timber, pulp or fuel) and the age of harvest. The weighted average of total standing biomass over the lifespan of a typical oil palm cycle, for example, was estimated at $28.0 \mathrm{t} \mathrm{C} \mathrm{ha}^{-1}$, with the total standing biomass of young oil palms ( $<5$ years) ranging typically between 2.2 and $13.5 \mathrm{t} \mathrm{C} \mathrm{ha}^{-1}$, and that of mature palms (5-28 years) ranging between 15.1 and $59.5 \mathrm{t} \mathrm{C} \mathrm{ha}^{-1}$ (Kho and Jepsen 2015).

\subsection{Reduced impact logging}

RIL seeks to minimise impacts through practices designed to reduce collateral damage from selective logging thereby reducing emissions and improving prospects for sustaining timber yields, biomass recovery and biodiversity (Ellis et al. 2019; Putz et al. 2008). Research into RIL tends to compare forests logged using RIL with forests logged using conventional forestry management. When the difference in logging intensity is controlled for, RIL has been found to provide fewer of the anticipated benefits (Burivalova et al. 2014; Griscom et al. 2017a; Martin et al. 2015; Sist et al. 2003; Zimmerman and Kormos 2012).

The determining factor in maintaining carbon stocks appears not to be collateral damage but logging intensity, i.e. the volume of timber extracted in the first cut and the frequency with which the forest is logged thereafter (Burivalova et al. 2014; Huang and Asner 2010; Martin et al. 2015; Putz et al. 2012; Rutishauser et al. 2015; Zimmerman and Kormos 2012)

Table 3 Key factors that should be considered when evaluating the validity of studies that compare the impacts of logging on ecosystem carbon stock losses and regrowth rates with estimates from pre- and unlogged forests

Comprehensiveness of the data

Carbon stock losses should include the timber volumes harvested, collateral damage, clearing for roads and infrastructure and edge effects.

Assessment of logging impacts should specify the logging regime and incorporate the effects when the regime has changed over time.

Analysis of carbon dynamics post-logging should include the removal of harvested logs, as well as longer-term losses due to damage, mortality and decomposition of dead biomass.

Reliability of estimates

Carbon stocks and stock changes estimated by remote sensing should be well-calibrated with field data.

Logging history of experimental sites must be well documented.

The baseline for reporting carbon stock loss should be the primary forest, where there is confidence in minimal human disturbance.

Calculation of carbon stocks based on inventory data should take account of species composition and the effect of wood density.

Comparability of data

The same type of forest ecosystem should be compared pre- and post-logging.

Site locations should be representative of the variability in the forest type across the landscape, including species and age structure.

Environmental conditions influencing productive capacity of the forest should be comparable. Often the most productive forest areas were harvested preferentially, leaving no comparable primary forest.

Inventory data from managed forests should include the full range in size/age structure of primary forests. Carbon stock components measured in logged and unlogged forest should be comparable. Comprehensive pools include the following: above-and below-ground living and dead biomass, coarse woody debris and soil organic carbon.

Measurement units for carbon should be comparable in terms of biomass or carbon, total carbon stock for a region/ecosystem or carbon stock density $\left(\mathrm{tC} \mathrm{ha}^{-1}\right)$. 
(Supplementary Material Fig. S3). As noted above, biomass carbon is concentrated in a relatively few large trees per hectare, and it is these trees that are targeted for logging.

Logging intensities in virtually all tropical forests are too high to sustain timber yields without extirpating commercial species within 2-3 logging rotations, and RIL alone cannot solve this problem (Free et al. 2017; Grogan et al. 2014; Putz et al. 2012; Richardson and Peres 2016; Rutishauser et al. 2015; Shearman et al. 2012; Zimmerman and Kormos 2012). It can no longer be assumed that a forest will recover on a trajectory toward its primary or predisturbance state, or keep biomass and biodiversity at their primary levels, after selective logging (Gatti et al. 2015; Huang and Asner 2010; Martin et al. 2015; Putz et al. 2012).

It is possible in theory to sustain timber yields by greatly extending logging rotations, reducing logging intensity, and requiring extensive RIL and other silvicultural practices (Putz et al. 2012; Zimmerman and Kormos 2012). Estimates of rotation lengths required to ensure regeneration of targeted hardwood species in tropical forests globally ranging from 50 to 100 years (Zimmerman and Kormos 2012; Putz et al. 2012; Piponiot et al. 2018; Griscom et al. $2017 \mathrm{a}, \mathrm{b})$. However, the high costs of RIL measures combined with the reduced profits from lower logging intensities make logging economically challenging (Zimmerman and Kormos 2012). Doing so would also require much greater knowledge than we currently have regarding the regeneration capacity of tropical forests (Laufer et al. 2013; Rutishauser et al. 2015).

\section{Discussion}

Protecting primary forests from deforestation and degradation delivers avoided emission plus ongoing sequestration. To date, these forests are typically labelled as 'unmanaged' and their protection has not been recognised as a mitigation strategy, even though their conservation increasingly requires active interventions and investments including by indigenous and local communities (Buckwell et al. 2019). Rather, the emphasis on forest management as a mitigation strategy has been on modifying conventional forest management for commodity production through SFM/RIL approaches and reforestation. SFM/RIL, however, has had little uptake in practice (Puettmann et al. 2015) which is perhaps one reason why reforestation continues to attract widespread attention and support (Bastin et al. 2019). In part, this is perhaps due to the emphasis found in international guidelines on 'additionality' when discussing the integrity of carbon offset projects (UNFCCC 2002). Additionality refers to the need to demonstrate that the avoided or reduced emissions would not have occurred in the absence of the mitigation action (Bayrak and Marafa 2016). It is relatively easier to demonstrate the additionality of a project's mitigation outcomes when it is based on planting trees on previously cleared land, especially if the land is degraded and natural regeneration has been unsuccessful. It is harder to demonstrate additionality in the absence of extant forest clearing and degradation even though throughout the world natural forests face growing threats that require management inputs, including forest areas previously thought to be secured from deforestation and degradation (Curtis et al. 2018; Ordway et al. 2019; Karky et al. 2013).

Proforestation in forests whose carbon stocks have been depleted through logging and other land use impacts is an important complementary mitigation action as it will increase the rate of biological carbon sequestration during the critical coming decades by refilling the ecosystem carbon stocks that have been deleted by prior land use. Proforestation is a nature-based solution whereby secondary forests are protected to foster continuous growth for maximal carbon storage and ecological and structural complexity. Importantly, as a mitigation strategy, 
it does not require additional land and, where natural regeneration is still possible, requires few energy or industrial inputs and is low cost compared with reforestation.

National circumstances play a major role in determining the opportunities that countries have to implement and prioritise forest-based mitigation strategies in the land sector. Tropical forests fall largely within just 15 countries (Saatchi et al. 2011), all of which face major development challenges. These countries vary in the percentage of their territory that is covered by primary forest, natural forest subject to conventional management for commodity production, and plantation forest. Where circumstances permit, primary forest protection and proforestation warrant being prioritised over SFM/RIL and new tree plantings as mitigation strategies. Indonesia, for example, has announced a permanent prohibition on the issuance of new permits to clear primary and peat forests which Indonesia's National Development Planning Agency (Badan Perencanaan Pembangunan Nasional-BAPPENAS) has described as the most efficient policy the Government of Indonesia can put in place to achieve greenhouse gas emission reduction targets (Eriksen 2019).

Where forests are being subject to conventional forestry management for commodity production, alternative silvicultural practices such as RIL can deliver some mitigation benefits. RIL still depletes forest carbon stocks compared to their primary state due to direct emissions, indirect damage, fragmentation, changed micro-climate, and rotation lengths that do not allow a positive net carbon balance between losses and gains. Any form of commercial logging reduces the carbon stock of primary tropical forests and hence contributes net emissions to the atmosphere principally because the larger trees are removed, and the remaining stands of smaller younger trees do not hold as much carbon as older ones. Furthermore, any mitigation benefits from applying RIL should be weighed against the benefits to be gained from ceasing commercial logging and allowing proforestation.

If the potential mitigation benefits of primary forest protection and proforestation are to be realised to any significant degree then supportive policies are needed, including in the rules and guidelines for the implementation of the Paris Agreement, so that countries have greater incentive to include these strategies in their nationally determined contributions. Changes required in the guidelines include, first, changes to the definitions of forests and what constitutes deforestation and degradation, so that the qualities of stability and longevity of the carbon stocks in primary forests are recognised and differentiated from the much lower carbon stocks in production forests and plantations.

Second, changes are needed in the systems of greenhouse gas accounting so that net accounting within the land sector, and across other sectors, cannot be used to mask the benefits arising from these mitigation actions: avoided emissions from protected forest should be added to not subtracted from the sequestered atmospheric withdrawals through proforestation (Ajani et al. 2013). Third, default values in carbon accounting guidance need to be revised to include values that are more characteristic of the range in carbon stocks found in forest biomes and ecosystem types, as well as values for carbon stock depletions that reflect logging intensity as well as the proportion of standing biomass.

At a landscape scale, the spatial configuration of forest-based mitigation interventions can produce synergies and co-benefits. Proforestation, reforestation and restoration can be used to buffer the boundaries of extensive areas of primary forests from land use pressures and other threats such as fire, as well as connecting remnant primary forest patches and aggregating them into more stable and resilient blocks. From this perspective, landscape conservation planning (Baldwin et al. 2018), with appropriately set objectives, can serve as a complementary strategy for improving mitigation outcomes. 
In summary, there is a substantive portfolio of forest-based mitigation actions available to policy and decision-makers, depending on national circumstances, in addition to SFM and plantation focused approaches, that can be grouped into four main strategies: (i) protection; (ii) proforestation, reforestation and restoration; (iii) reform of guidelines, accounting rules and default values; (iv) landscape conservation planning (Table 4).

\section{Conclusion}

Mitigation pathways that can limit global warming to $1.5^{\circ} \mathrm{C}$ above pre-industrial levels require deep and rapid cuts in emissions from all sources while simultaneously increasing $\mathrm{CO}_{2}$ removal by the land sector, including the contribution from conserving and protecting land carbon stocks (IPCC 2018). Given this mitigation imperative, strategies that merely aim to reduce the rate of emissions against historic or projected reference levels are insufficient, even if better than a business-as-usual approach. Strategies are needed that explicitly avoid emissions where possible as well as enabling ongoing sequestration.

Carbon neutrality - if calculated through accounts that offset current emissions into the atmosphere with removals - is insufficient to meet the agreed climate goal of stabilising greenhouse gas concentrations in the atmosphere at a level that would prevent dangerous

Table 4 Key primary forest-orientated mitigation strategies and examples of management actions and other supportive and capacity building interventions

\begin{tabular}{|c|c|}
\hline Strategy & Supportive actions and interventions \\
\hline Protection & $\begin{array}{l}\text { - Identify areas of primary forest with high biomass stocks } \\
\text { - Legislate and manage for protection } \\
\text { - Governance and enforcement of protection status } \\
\text { - Empower indigenous communities to protect their land } \\
\text { - Industry re-adjustment to source alternative fuel, food and wood } \\
\text { products } \\
\text { - Control weeds, pests and feral animals } \\
\text { - Control livestock grazing }\end{array}$ \\
\hline $\begin{array}{l}\text { Proforestation, restoration and } \\
\text { reforestation }\end{array}$ & $\begin{array}{l}\text { - Identify areas of secondary native forest to cease harvesting } \\
\text { - Industry re-adjustment to increase wood production from plantations } \\
\text { - Legislate and manage for protection of forest regrowth; } \\
\text { - Control grazing to allow natural regeneration } \\
\text { - Planting under existing trees and with mixed native tree species } \\
\text { - Erosion prevention measures }\end{array}$ \\
\hline $\begin{array}{l}\text { Reform of guidelines, accounting } \\
\text { rules and default values }\end{array}$ & $\begin{array}{l}\text { - Include all lands in comprehensive accounts, irrespective of degree of } \\
\text { human management } \\
\text { - The reference level for accounting should be the natural carbon } \\
\text { carrying capacity of the ecosystem } \\
\text { - Differentiate the qualities of carbon stocks in terms of their longevity, } \\
\text { stability and capacity for restoration } \\
\text { - Classify the reservoirs for carbon stocks in forests as primary, } \\
\text { production and plantation } \\
\text { - Forest' defined as a land cover type refers to the actual vegetation } \\
\text { cover at the time of accounting, not the potential vegetation type } \\
\text { - Report gross flows not net flows }\end{array}$ \\
\hline Landscape conservation planning & $\begin{array}{l}\text { - Utilise systematic conservation planning to optimise spatial placement } \\
\text { of forest-based interventions } \\
\text { - Direct reforestation projects to buffer the boundaries of primary forests } \\
\text { and connect and aggregate remnant patches }\end{array}$ \\
\hline
\end{tabular}


anthropogenic interference with the climate system (UN 1992). As the world community now needs to become 'carbon negative', all emissions, including from land use impacts on ecosystems and bioenergy production, and all removals by forests and other land sinks, must be accounted for separately to ensure that the emission gap is being closed.

Acknowledgements The research reported here was supported in part by a private charitable trust that wishes to remain anonymous to avoid unsolicited funding requests. The trust has had no influence on the design, analysis, interpretation and documentation of this research.

Open Access This article is distributed under the terms of the Creative Commons Attribution 4.0 International License (http://creativecommons.org/licenses/by/4.0/), which permits unrestricted use, distribution, and reproduction in any medium, provided you give appropriate credit to the original author(s) and the source, provide a link to the Creative Commons license, and indicate if changes were made.

\section{References}

Ajani J, Keith H, Blakers M, Mackey BG, King HP (2013) Comprehensive carbon stock and flow accounting: a national framework to support climate change mitigation policy. Ecol Econ 89:61-72. https://doi. org/10.1016/j.ecolecon.2013.01.010

Asner GP, Knapp DE, Broadbent EN et al (2005) Selective logging in the Brazilian Amazon. Science 310:480482

Asner GP, Broadbent EN, Oliveira PJ, Keller M, Knapp DE, Silva JNM (2006) Condition and fate of logged forests in the Brazilian Amazon. Proc Natl Acad Sci U S A 103(34):12947-12950

Asner GP, Powell GVN, Mascaro J, Knapp DE, Clark JK, Jacobson J, Kennedy-Bowdoin T, Balaji A, PaezAcosta G, Victoria E, Secada L, Valqui M, Hughes RF (2010) High-resolution forest carbon stocks and emissions in the Amazon. Proc Natl Acad Sci U S A 107(38):16738-16742. https://doi.org/10.1073 /pnas. 1004875107

Avitabile V, Herold M, Heuvelink GBM, Lewis SL, Phillips OL, Asner GP, Armston J, Ashton PS, Banin L, Bayol N, Berry NJ, Boeckx P, de Jong BHJ, DeVries B, Girardin CAJ, Kearsley E, Lindsell JA, LopezGonzalez G, Lucas R, Malhi Y, Morel A, Mitchard ETA, Nagy L, Qie L, Quinones MJ, Ryan CM, Ferry SJW, Sunderland T, Laurin GV, Gatti RC, Valentini R, Verbeeck H, Wijaya A, Willcock S (2016) An integrated pan-tropical biomass maps using multiple reference datasets. Glob Chang Biol 22:1406-1420. https://doi.org/10.1111/gcb.13139

Baccini A, Walker W, Carvalho L, Farina M, Sulla-Menashe D, Houghton RA (2017) Tropical forests are a net carbon source based on above-ground measurements of gains and losses. Science 358:230-234

Baldwin RF, Trombulak SC, Leonard PB, Noss RF, Hilty JA, Possingham HP, Anderson MG (2018) The future of landscape conservation. BioScience 68:60-63. https://doi.org/10.1093/biosci/bix 142

Barber CP, Cochrane MA, Souza CM, Laurance WF (2014) Roads, deforestation and the mitigating effect of protected areas in the Amazon. Biol Conserv 177:203-209

Bastin J, Fingold Y, Garcia C et al (2019) The global tree restoration potential. Science 365(6448):76-79. https://doi.org/10.1126/science.aax0848

Bayrak MM, Marafa LM (2016) Ten years of REDD+: a critical review of the impact of REDD+ on forestdependent communities. Sustainability (Switzerland) 8(7):1-22. https://doi.org/10.3390/su8070620

Benitez-López A, Santini L, Schipper AM, Busana M, Huijbregts MAJ (2019) Intact but empty forests? Patterns of hunting-induced mammal defaunation in the tropics. PLoS Biol 17. https://doi.org/10.1371/journal.pbio.3000247

Berenguer E, Gardner TA, Ferreira J, Aragão LEOC, Mac Nally R, Thomson JR, Barlow J (2018) Seeing the woods through the saplings: Using wood density to assess the recovery of human modified Amazonian forests. J Ecol 106(6):2190-2220

Blanc L, Echard M, Herault B, Bonal D, Marcon E, Chave J, Baraloto C (2009) Dynamics of above-ground carbon stocks in a selectively logged tropical forest. Ecol Appl 19(6):1397-1404

Boakes EH, Mace GM, McGowan PJK, Fuller RA (2010) Extreme contagion in global habitat clearance. Proc R Soc Ser B-Biol 277:1081-1085. https://doi.org/10.1098/rspb.2009.1771

Brinck K, Fischer R, Groeneveld J, Lehmann S, Dantas de Paula M, Pütz S, Sexton JO, Song D, Huth A (2017) High resolution analysis of tropical forest fragmentation and its impact on the global carbon cycle. Nat Commun 8:14855. https://doi.org/10.1038/ncomms14855 
Bryan J, Shearman P, Ash J, Kirkpatrick JB (2010) Impact of logging on above-ground biomass stocks in lowland rain forest, Papua New Guinea. Ecol Appl 20(8):2096-2103

Bryan JE, Shearman PL, Asner GP, Knapp DE, Aoro G, Lokes B (2013) Extreme differences in forest degradation in Borneo: comparing practices in Sarawak, Sabah and Brunei. PLoS One 8(7):e69679

Buchwald E (2005) A hierarchical terminology for more or less natural forests in relation to sustainable management and biodiversity conservation. Third Expert Meeting on Harmonizing Forest-Related Definitions. Danish Forest and Nature Agency

Buckwell A, Ware D, Fleming C, Smart JCR, Mackey B, Nalau J, Dan A (2019) Social benefit cost analysis of ecosystem-based climate change adaptations: a community-level case study in Tanna Island, Vanuatu. Clim Dev:1-16. https://doi.org/10.1080/17565529.2019.1642179

Burivalova Z, Sekercioglu CH, Koh LP (2014) Thresholds of logging intensity to maintain tropical forest biodiversity. Curr Biol 24:1893-1898

Bustamente MMC, Roitman I, Aide TM (2016) Toward an integrated monitoring framework to assess the effects of tropical forest degradation and recovery on carbon stocks and biodiversity. Glob Chang Biol 22:92-109

Castanho A, Galbraith D, Zhang K, Coe MT, Costa MH, Moorcroft P (2016) Changing Amazon biomass and the role of atmospheric $\mathrm{CO}_{2}$ concentration, climate and land use. Glob Biogeochem Cycles 30:18-39

Chaudhary A, Burivalova Z, Koh LP, Hellweg S (2016) Impact of forest management on species richness: global meta-analysis and economic trade-offs. Sci Rep-UK 6:23954. https://doi.org/10.1038/srep23954

Chazdon RL, Finegan B, Capers RS, Salgado-Negret B, Casanoves F, Boukili V, Norden N (2010) Composition and dynamics of functional groups of trees during tropical forest succession in Northeastern Costa Rica. Biotropica 42(1):31-40. https://doi.org/10.1111/j.1744-7429.2009.00566.x

Cochrane MA (2003) Fire science for rainforests. Nature 42:913-919

Curtis PG, Slay CM, Harris NL, Tyukavina A, Hansen MC (2018) Classifying drivers of global forest loss. Science 361:1108-1111

Dinerstein E, Olson D, Joshi A, Vynne C, Burgess ND, Wikramanayake E, Hahn N, Palminteri S, Hedao P, Noss R, Hansen M, Locke H, Ellis EC, Jones B, Barber CV, Hayes R, Kormos C, Martin V, Crist E, Sechrest W, Price L, Baillie JEM, Weeden D, Suckling K, Davis C, Sizer N, Moore R, Thau D, Birch T, Potapov P, Turubanova S, Tyukavina A, de Souza N, Pintea L, Brito JC, Llewellyn OA, Miller AG, Patzelt A, Ghazanfar SA, Timberlake J, Klöser H, Shennan-Farpón Y, Kindt R, Lillesø JPB, van Breugel P, Graudal L, Voge M, al-Shammari KF, Saleem M (2017) An ecoregion-based approach to protecting half the terrestrial realm. BioScience 67(6):534-545

Donohue RJ, Roderick ML, McVicar TR, Farquhar GD (2013) Impact of $\mathrm{CO}_{2}$ fertilization on maximum foliage cover across the globe's warm, arid environments. Geophys Res Lett 40(12):3031-3035 http://doi.wiley. com/10.1002/grl.50563

Ellis EC, Goldewijk KK, Siebert S, Lightman D, Ramankutty N (2010) Anthropogenic transformation of the biomes, 1700 to 2000. Glob Ecol Biogeogr 19(5):589-606. https://doi.org/10.1111/j.1466-8238.2010.00540.x

Ellis PW, Gopalakrishna T, Goodman RC, Putz FE, Roopsind A, Umunay PM, Zalman J, Ellis EA, Mo K, Gregoire TG, Griscom BW (2019) Reduced-impact logging for climate change mitigation (RIL_C) can halve selective logging emissions from tropical forests. For Ecol Manag 438:255-266

Erb KH, Kastner T, Plutzar C et al (2017) Unexpectedly large impact of forest management and grazing on global vegetation biomass. Nature 553:73-76

Eriksen S (2019) Indonesia's primary forest and peatland moratorium now permanent. Rainforest Foundation Norway - News, 14 August 2019. https://www.regnskog.no/en/news/indonesias-primary-forest-andpeatland-moratorium-now-permanent-1. Accessed 27 August 2019

FAO (2012) Global ecological zones for FAO forest reporting: 2010 update. Food and Agriculture Organization of the United Nations, Rome. http://www.fao.org/forest-resources-assessment/remote-sensing/globalecological-zones-gez-mapping/en/. Accessed 9 August 2019

FAO (2015) Global forest resources assessment 2015 how are the world's forests changing? Second edn. Food and Agricultural Organization of the United Nations

FAO and ITPS (2017) Global soil organic carbon map. Food and Agricultural Organisation of the United Nations and the Intergovernmental Technical Panel: Global Soil Partnership http://54.229.242.119/GSOCmap/

FAO (2018) Global forest resources assessment 2020. Terms and definitions FRA 2020. Food and Agriculture Organization. Forest Resources Working Paper 188

Fauset S, Johnson MO, Gloor M, Baker TR, Monteagudo M. A, Brienen RJW, Feldpausch TR, Lopez-Gonzalez G, Malhi Y, ter Steege H, Pitman NCA, Baraloto C, Engel J, Pétronelli P, Andrade A, Camargo JLC, Laurance SGW, Laurance WF, Chave J, Allie E, Vargas PN, Terborgh JW, Ruokolainen K, Silveira M, Aymard C. GA, Arroyo L, Bonal D, Ramirez-Angulo H, Araujo-Murakami A, Neill D, Hérault B, Dourdain A, Torres-Lezama A, Marimon BS, Salomão RP, Comiskey JA, Réjou-Méchain M, Toledo M, Licona JC, Alarcón A, Prieto A, Rudas A, van der Meer PJ, Killeen TJ, Marimon Junior BH, Poorter L, Boot RGA, 
Stergios B, Torre EV, Costa FRC, Levis C, Schietti J, Souza P, Groot N, Arets E, Moscoso VC, Castro W, Coronado ENH, Peña-Claros M, Stahl C, Barroso J, Talbot J, Vieira ICG, van der Heijden G, Thomas R, Vos VA, Almeida EC, Davila EÁ, Aragão LEOC, Erwin TL, Morandi PS, de Oliveira EA, Valadão MBX, Zagt RJ, van der Hout P, Loayza PA, Pipoly JJ, Wang O, Alexiades M, Cerón CE, Huamantupa-Chuquimaco I, di Fiore A, Peacock J, Camacho NCP, Umetsu RK, de Camargo PB, Burnham RJ, Herrera R, Quesada CA, Stropp J, Vieira SA, Steininger M, Rodríguez CR, Restrepo Z, Muelbert AE, Lewis SL, Pickavance GC, Phillips OL (2015) Hyperdominance in Amazonian forest carbon cycling. Nat Commun 6:6857. https://doi. org/10.1038/ncomms7857

Ferreira J, Lennox GD, Gardner TA, Thomson JR, Berenguer E, Lees AC, Mac Nally R, Aragão LEOC, Ferraz SFB, Louzada J, Moura NG, Oliveira VHF, Pardini R, Solar RRC, Vieira ICG, Barlow J (2018) Carbonfocused conservation may fail to protect the most biodiverse tropical forests. Nat Clim Chang 8:744-749. https://doi.org/10.1038/s41558-018-0225-7

Figueres C (2017) Three years to safeguard our climate. Nature 546:593-595

Finer M, Jenkins CN, Sky MAS, Pine J (2014) Logging concessions enable illegal logging crisis in the Peruvian Amazon. Sci Rep-UK 4:4719. https://doi.org/10.1038/srep04719

Free CM, Grogan J, Schulze MD, Landis RM, Brienen RJW (2017) Current Brazilian forest management guidelines are unsustainable for Swietenia, Cedrela, Amburana and Copaifera: a response to da Cunha and colleagues. For Ecol Manag 386:81-83

Funk JM, Aguilar-Amuchastegui N, Baldwin-Cantello W, Busch J, Chuvasov E, Evans T, Griffin B, Harris N, Ferreira MN, Petersen K, Phillips O, Soares MG, van der Hoff RJA (2019) Securing the climate benefits of stable forests. Clim Pol 19:845-860. https://doi.org/10.1080/14693062.2019.1598838

Garnett ST, Burgess ND, Fa JA et al (2018) Indigenous lands for conservation. Nat Sustain 1(July):369-374. https://doi.org/10.1038/s41893-018-0100-6

Gatti RC, Castaldi S, Lindsell JA et al (2015) The impact of selective logging and clearcutting on forest structure, tree diversity and above-ground biomass of African tropical forests. Ecol Res 30(1):119-132

Gaubert B, Stephens BB, Basu S, Chevallier F, Deng F, Kort EA, Patra PK, Peters W, Rödenbeck C, Saeki T, Schimel D, van der Laan-Luijkx I, Wofsy S, Yin Y (2019) Global atmospheric $\mathrm{CO}_{2}$ inverse models converging on neutral tropical land exchange, but disagreeing on fossil fuel and atmospheric growth rate. Biogeosciences 16:117-134

Giardina F, Konings AG, Kennedy D, Alemohammad SH, Oliveira RS, Uriarte M, Gentine P (2018) Tall Amazonian forests are less sensitive to precipitation variability. Nat Geosci 11:405-409. https://doi. org/10.1038/s41561-018-0133-5

Gibbs H, Ruesch AS, Achard F, Clayton MK, Holmgren P, Ramankutty N, Foley JA (2010) Tropical forests were the primary sources of new agricultural land in the 1980s and 1990s. Proc Natl Acad Sci U S A 107(38): 16732-16737

Global Carbon Project (2018) Global Carbon Budget 2018. https://www.globalcarbonproject. org/carbonbudget/index.htm. Accessed 9 August 2019

Grace J, Mitchard E, Gloor E (2014) Perturbations in the carbon budget in the tropics. Glob Chang Biol 20:3238-3255

Grassi G, House J, Dentener F, Federici S, den Elzen M, Penman J (2017) The key role of forests in meeting climate targets requires science for credible mitigation. Nat Clim Chang 7:220-226

Griscom BW, Adams J, Ellis PW, Houghton RA, Lomax G, Miteva DA, Schlesinger WH, Shoch D, Siikamäki JV, Smith P, Woodbury P, Zganjar C, Blackman A, Campari J, Conant RT, Delgado C, Elias P, Gopalakrishna T, Hamsik MR, Herrero M, Kiesecker J, Landis E, Laestadius L, Leavitt SM, Minnemeyer S, Polasky S, Potapov P, Putz FE, Sanderman J, Silvius M, Wollenberg E, Fargione J (2017a) Natural climate solutions. Proc Natl Acad Sci U S A 114(44):11645-11650

Griscom BW, Ellis P, Putz FE (2017b) Carbon emissions performance of commercial logging in East Kalimantan, Indonesia. Glob Chang Biol 20:923-937

Grogan J, Landis RM, Free CM, Schulze MD, Lentini M, Ashton MS (2014) Big-leaf mahogany Swietenia macrophylla population dynamics and implication for sustainable. J Appl Ecol 51:664-674

Günter SM, Weber M, Mosandl SB (eds) (2011) Silviculture in the tropics. Springer, Freisig

Haddad NM, Brudvig LA, Clobert J, Davies KF, Gonzalez A, Holt RD, Lovejoy TE, Sexton JO, Austin MP, Collins CD, Cook WM, Damschen EI, Ewers RM, Foster BL, Jenkins CN, King AJ, Laurance WF, Levey DJ, Margules CR, Melbourne BA, Nicholls AO, Orrock JL, Song DX, Townshend JR (2015) Habitat fragmentation and its lasting impact on Earth's ecosystems. Sci Adv 1:e1500052

Hamburg SP, Vadeboncoeur MA, Johnson C, Sanderman J (2019) Losses of mineral soil carbon largely offsets biomass accumulation 15 years after whole-tree harvest. Biogeochemistry. 144:1-14. https://doi.org/10.1007 /s10533-019-00568-3

Hansen MC, Potapov PV, Moore R, Hancher M, Turubanova S, Tyukavina A, Loveland TR (2013) Highresolution global maps of 21st-century forest cover change. Science 342(6160):850-853 
Harmon M (2019) Have product substitution carbon benefits been overestimated? A sensitivity analysis of key assumptions. Environ Res Lett 14(6) https://iopscience.iop.org/article/10.1088/1748-9326/ab1e95

Harris NL, Brown S, Hagen SC, Saatchi SS, Petrova S, Salas W, Hansen MC, Potapov PV, Lotsch A (2012) Baseline map of carbon emissions from deforestation in tropical regions. Science 336:1573-1576

Hoare A (2015) Tackling illegal logging and the related trade: what progress and where next? Chatham house report. The Royal Institute of International Affairs, London https://www.chathamhouse. org/sites/default/files/publications/research/20150715IllegalLoggingHoareFinal.pdf. Accessed 9 August 2019

Houghton RA (2013) The emissions of carbon from deforestation and degradation in the tropics: past trends and future potential. Carbon Manag 4(5):539-546

Houghton RA, Nassikas AA (2018) Negative emissions from stopping deforestation and forest degradation. Glob Chang Biol 24:350-359

Huang M, Asner GP (2010) Long-term carbon loss and recovery following selective logging in Amazon forests. Glob Biogeochem Cycles 24:GB3028. https://doi.org/10.1029/2009GB003727

Ibisch PL, Hoffmann MT, Kreft S et al (2017) A global map of roadless areas and their conservation status. Science 354(6318):1423-1427

IPCC (2006) 2006 IPCC Guidelines for National Greenhouse Gas Inventories, prepared by the National Greenhouse Gas Inventories Programme. In: Eggleston HS, Buendia L, Miwa K, Ngara T, Tanabe K (eds). Published: IGES, Japan

IPCC (2018) Summary for policymakers. In: Masson-Delmotte V, Zhai P, -O. Pörtner H et al. (eds) Global warming of $1.5^{\circ} \mathrm{C}$. An IPCC special report on the impacts of global warming of $1.5^{\circ} \mathrm{C}$ above pre-industrial levels and related global greenhouse gas emission pathways, in the context of strengthening the global response to the threat of climate change, sustainable development, and efforts to eradicate poverty, In Press

IUCN (2011) International union for conservation of nature and the global partnership on forest landscape restoration. The Bonn Challenge. http://www.bonnchallenge.org/content/challenge. Accessed 9 August 2019

Karky BS, Vaidya R, Karki S, Tulachan B (2013) What is REDD+ additionality in community managed forest for Nepal? J For Livelihood 11(2):37-45. https://doi.org/10.3126/jfl.v11i2.8620

Keenan RJ, Reams GA, Achard F, de Freitas JV, Grainger A, Lindquist E (2015) Dynamics of global forest area: results from the FAO global forest resources assessment 2015. For Ecol Manag 352:9-20

Keith H, Mackey B, Lindenmayer D (2009) Re-evaluation of forest biomass carbon stocks and lessons from the world's most carbon-dense forests. Proc Natl Acad Sci U S A 106:11635-11640 www.pnas. org/cgi/doi:10.1073/pnas.0901970106

Keith H, Mackey BG, Berry S, Lindenmayer DB, Gibbons P (2010) Estimating carbon carrying capacity in natural forest ecosystems across heterogeneous landscapes: addressing sources of error. Glob Chang Biol 16: 2971-2989. https://doi.org/10.1111/j.1365-2486.2009.02146.x

Keith H, Lindenmayer D, Macintosh A, Mackey B (2015) Under what circumstances do wood products from native forests benefit climate change mitigation? PLoS One 10(10):e0139640. https://doi.org/10.1371 /journal.pone.0139640

Kho LK, Jepsen MR (2015) Carbon stock of oil palm plantations and tropical forests in Malaysia: a review. Singapore J Trop Geog 36:249-266

Köhl M, Neupane PR, Lotfiomran N (2017) The impact of tree age on biomass growth and carbon accumulation capacity: a retrospective analysis using tree ring data of three tropical tree species grown in natural forests in Suriname. PLoS One 12:e0181187. https://doi.org/10.1371/journal.pone.0181187

Körner C (2017) A matter of tree longevity. Science 355(6321):130-131

Laufer J, Michalski F, Peres CA (2013) Assessing sampling biases in logging impact studies in tropical forests. Trop Cons Sci 6(1):16-34

Laurance WF, Balmford A (2013) A global map for road building. Nature 495:308-309

Laurance WF, Sayer J, Cassman KG (2014) Agricultural expansion and its impacts on tropical nature. Trends Ecol Evol 29(2):107-116

Lawson S (2014) Illegal wood import and re-export: the scale of the problem and the response in Thailand, South Korea and India. Chatham House Report. The Royal Institute of International Affairs, London UK. https://www.chathamhouse.org/sites/default/files/home/chatham/public_html/sites/default/files/20140400 IllegalWoodThailandSKIndiaLawson.pdf. Accessed 9 August 2019

Lawson S, MacFaul L (2010) Illegal logging and related trade indicators of the global response. Chatham House (The Royal Institute of International Affairs). https://indicators.chathamhouse.org/publications?page=2

Lesslie RG, Mackey BG, Preece KM (1988) A computer-based methodology for the survey of wilderness in Australia. Environ Conserv 15:225-232

Lewis SL, Lopez-Gonzalez G, Sonke B et al (2009) Increasing carbon storage in intact African tropical forests. Nature 457:1003-1006

Lewis SL, Wheeler CE, Mitchard ETA, Koch A (2019) Regenerate natural forests to store carbon. Nature 608: $25-28$ 
Liu X, Trogisch S, He JS, Niklaus PA, Bruelheide H, Tang Z, Erfmeier A, Scherer-Lorenzen M, Pietsch KA, Yang B, Kühn P, Scholten T, Huang Y, Wang C, Staab M, Leppert KN, Wirth C, Schmid B, Ma K (2018) Tree species richness increases ecosystem carbon storage in subtropical forests. Proc R Soc Ser B-Biol 285: 20181240

Lund HG (2014) What is a forest? Definitions do make a difference an example from Turkey. Avrasya Terim Dergisi 2(1):1-8

Lutz JA, Furniss TJ, Johnson DJ (2018) Global importance of large-diameter trees. Glob Ecol Biogeogr 2018:116

Mackey B, DellaSala DA, Kormos et al (2015) Policy options for the world's primary forests in multilateral environmental agreements. Conserv Lett 8:139-147

Mackey B, Keith H, Berry S, Lindenmayer DB (2008) Green carbon: the role of natural forests in carbon storage. Part 1. A green carbon account of the eucalypt forests of south east Australia. Australian National University Press, Canberra. https://doi.org/10.22459/GC.08.2008

Mackey B, Prentice IC, Steffen W, House JI, Lindenmayer D, Keith H, Berry S (2013) Untangling the confusion around land carbon science and climate change mitigation policy. Nat Clim Chang 3:552-557. https://oi. org/10.1038/nclimate1804

Martin PA, Newton AC, Pfeifer M, Khoo M, Bullock JM (2015) Impacts of tropical selective logging on carbon storage and tree species richness: a meta-analysis. For Ecol Manag 356:224-233

Matricardi EAT, Skole DL, Pedlowski MA, Chomentowski W, Fernandes LC (2010) Assessment of tropical forest degradation by selective logging and fire using Landsat imagery. Remote Sens Environ 114:11171129

Millar RJ, Fuglestvedt JS, Friedlingstein P et al (2017) Emission budgets and pathways consistent with limiting warming to $1.5^{\circ} \mathrm{C}$. Nat Geosci. https://doi.org/10.1038/NGEO3031

Mitchard ETA (2018) The tropical forest carbon cycle and climate change. Nature 559:527-534

Mokany K, Raison RJ, Prokushkin AS (2006) Critical analysis of root:shoot rations in terrestrial biomes. Glob Chang Biol 12:84-96

Moomaw WR, Masino SA, Faison EK (2019) Intact forests in the United States: proforestation mitigates climate change and serves the greatest good. Front For Glob Chang 2. https://doi.org/10.3389/ffgc.2019.00027

Morales-Hidalgo D, Oswalt SN, Somanathan E (2015) Status and trends in global primary forest, protected areas, and areas designated for conservation of biodiversity from the global forest resources assessment 2015. For Ecol Manag 352:68-77

Navarrete-Segueda A, Martinez-Ramos M, Ibarra-Manriquez G, Vazquez-Selem L, Siebe C (2018) Variation in main terrestrial carbon stocks at landscape-scale are shaped by soil in a tropical rainforest. Geoderma 313:57-68

Nemani RR, Keeling CD, Hashimoto $\mathrm{H}$ et al (2003) Climate-driven increases in global terrestrial net primary production from 1982 to 1999 . Science 300:1560-1563

Ordway EM, Naylor RL, Nkongho RN, Lambin EF (2019) Oil palm expansion and deforestation in Southwest Cameroon associated with proliferation of informal mills. Nat Commun 10(1):1-11. https://doi.org/10.1038 /s41467-018-07915-2

Pan Y, Birdsey RA, Fang J, Houghton R, Kauppi PE, Kurz WA, Phillips OL, Shvidenko A, Lewis SL, Canadell JG, Ciais P, Jackson RB, Pacala SW, McGuire AD, Piao S, Rautiainen A, Sitch S, Hayes D (2011) A large and persistent carbon sink in the world's forests. Science 333:988-993

Pearson TRH, Brown S, Casarim FM (2014) Carbon emissions from tropical forest degradation caused by logging. Environ Res Lett 9:034017

Pearson TRH, Brown S, Murray L, Sidman G (2017) Greenhouse gas emissions from tropical forest degradation: an underestimated source. Carbon Balance Manag 12:3. https://doi.org/10.1186/s13021-017-0072-2

Pendrill F, Persson UM, Godar J, Kastner T, Moran D, Schmidt S, Wood R (2019) Agricultural and forestry trade drives large share of tropical deforestation emissions. Glob Environ Chang 56:1-10

Penman J, Gytarsky M, Hiraishi T et al (2003) Good practice guidance for land use, land use change, and forestry. Institute for Global Environmental Strategies for the Intergovernmental Panel on Climate Change, Hayama 502 p

Pinard MA, Cropper WP (2000) Simulated effects of logging on carbon storage in dipterocarp forest. J Appl Ecol 37:267-283

Piponiot C, Derroire G, Descroix L, Mazzei L, Rutishauser E, Sist P, Hérault B (2018) Assessing timber volume recovery after disturbance in tropical forests - a new modelling framework. Ecol Model 384:353-369

Potapov P, Hansen MC, Laestadius L et al (2017) The last frontiers of wilderness: tracking loss of intact forest landscapes from 2000 to 2013. Sci Adv 3(1):e1600821. https://doi.org/10.1126/sciadv.1600821

Puettmann KJ, Wilson SMCG, Baker SC et al (2015) Silvicultural alternatives to conventional even-aged forest management - what limits global adoption? For Ecosyst 2(1). https://doi.org/10.1186/s40663-015-0031-x

Putz FE, Redford KH, Robinson JG, Fimbel R, Blate GM (2000) Biodiversity conservation in the context of tropical forest management. The World Bank, Washington, DC 
Putz FE, Sist P, Fredericksen T, Dykstra D (2008) Reduced impact logging: challenges and opportunities. Forest Ecol Manag 256:1427-1433

Putz FE, Zuidema PA, Synnott T, Peña-Claros M, Pinard MA, Sheil D, Vanclay JK, Sist P, Gourlet-Fleury S, Griscom B, Palmer J, Zagt R (2012) Sustaining conservation values in selectively logged tropical forests: the attained and the attainable. Conserv Lett 5:296-303

Richardson VA, Peres CA (2016) Temporal decay in timber species composition and value in Amazonian logging concessions. PLoS One 11:e0159035. https://doi.org/10.1371/journal.pone.0159035

Ricketts TH, Soares-filho B, Fonseca GAB et al (2010) Indigenous lands, protected areas, and slowing climate change. PLoS Biol 8(3):6-9. https://doi.org/10.1371/journal.pbio.1000331

Rockström J, Williams J, Daily G, Noble A, Matthews N, Gordon L, Wetterstrand H, DeClerck F, Shah M, Steduto P, de Fraiture C, Hatibu N, Unver O, Bird J, Sibanda L, Smith J (2017) Sustainable intensification of agriculture for human prosperity and global sustainability. Ambio 46:4-17

Rogelj J, Ludere G, Pietzcker RC (2015) Energy system transformations for limiting end-of-century warming to below $1.5^{\circ} \mathrm{C}$. Nat Clim Chang 5:519-527. https://doi.org/10.1038/nclimate2572

Rutishauser E, Herault B, Baraloto C et al (2015) Rapid tree carbon recovery in managed Amazonian forests. Curr Biol 25:R775-R792

Saatchi SS, Harris NL, Brown S, Lefsky M, Mitchard ETA, Salas W, Zutta BR, Buermann W, Lewis SL, Hagen S, Petrova S, White L, Silman M, Morel A (2011) Benchmark map of forest carbon stocks in tropical regions across three continents. Proc Natl Acad Sci U S A 108(24):9899-9904

Santoro M, Mermoz CO, Bouvet S et al (2018) GlobBiomass: global above-ground biomass and growing stock volume datasets available on-line at http://globbiomass.org/products/global-mapping. Accessed 9 August 2019

Sasaki N, Asner GP, Pan Y, Knorr W, Durst PB, Ma HO, Abe I, Lowe AJ, Koh LP, Putz FE (2016) Sustainable management of tropical forests can reduce carbon emissions and stabilize timber production. Front Environ Sci 4:50. https://doi.org/10.3389/fenvs.2016.00050

Schulze M, Zweede J (2006) Canopy dynamics in unlogged and logged forest stands in the eastern Amazon. For Ecol Manag 236:56-64

Shearman P, Bryan J, Laurance WF (2012) Are we approaching 'peak timber' in the tropics? Biol Conserv 151: $17-21$

Sist P, Picard N, Gourlet-Fleury S (2003) Sustainable cutting cycle and yields in a lowland mixed dipterocarp forest in Borneo. Ann For Sci 60:803-814

Sist P, Mazzei L, Blanc L, Rutishauser E (2014) Large trees as key elements of carbon storage and dynamics after selective logging in the Eastern Amazon. For Ecol Manag 318:103-109

Slik JWF, Paoli G, McGuire K, Amaral I, Barroso J, Bastian M, Blanc L, Bongers F, Boundja P, Clark C, Collins M, Dauby G, Ding Y, Doucet JL, Eler E, Ferreira L, Forshed O, Fredriksson G, Gillet JF, Harris D, Leal M, Laumonier Y, Malhi Y, Mansor A, Martin E, Miyamoto K, Araujo-Murakami A, Nagamasu H, Nilus R, Nurtjahya E, Oliveira Á, Onrizal O, Parada-Gutierrez A, Permana A, Poorter L, Poulsen J, Ramirez-Angulo H, Reitsma J, Rovero F, Rozak A, Sheil D, Silva-Espejo J, Silveira M, Spironelo W, ter Steege H, Stevart T, Navarro-Aguilar GE, Sunderland T, Suzuki E, Tang J, Theilade I, van der Heijden G, van Valkenburg J, van Do T, Vilanova E, Vos V, Wich S, Wöll H, Yoneda T, Zang R, Zhang MG, Zweifel N (2013) Large trees drive forest above-ground biomass variation in moist lowland forests across the tropics. Glob Ecol Biogeogr 22:1261-1271

Smith JE, Linda SH, Hoover CM (2013) Carbon factors and models for forest carbon estimates for the 20052011 national greenhouse gas inventories of the United States. For Ecol Manag 307:7-19. https://oi. org/10.1016/j.foreco.2013.06.061

Stephenson NL, Das AJ, Condit R, Russo SE, Baker PJ, Beckman NG, Coomes DA, Lines ER, Morris WK, Rüger N, Álvarez E, Blundo C, Bunyavejchewin S, Chuyong G, Davies SJ, Duque Á, Ewango CN, Flores O, Franklin JF, Grau HR, Hao Z, Harmon ME, Hubbell SP, Kenfack D, Lin Y, Makana JR, Malizia A, Malizia LR, Pabst RJ, Pongpattananurak N, Su SH, Sun IF, Tan S, Thomas D, van Mantgem PJ, Wang X, Wiser SK, Zavala MA (2014) Rate of tree carbon accumulation increases continuously with tree size. Nature 507:90-93

Taubert F, Fischer R, Groeneveld J, Lehmann S, Müller MS, Rödig E, Wiegand T, Huth A (2018) Global patterns of tropical forest fragmentation. Nature 554:519-522

Turubanova S, Potapov PV, Tyukavina A, Hansen MC (2018) Ongoing primary forest loss in Brazil, Democratic Republic of the Congo, and Indonesia. Environ Res Lett 13(7). https://doi.org/10.1088/1748-9326/aacd1c

Tyukavina A, Hansen MC, Potapov OV, Krylov AM, Goetz SJ (2016) Pan-tropical hinterland forests: mapping minimally disturbed forests. Glob Ecol Biogeogr 25:151-163

Uhl C, Kauffman JB (1990) Deforestation, fire susceptibility, and potential tree responses to fire in the eastern Amazon. Ecology 71(2):437-449

UN (1992) Article 2 United Nations framework convention on climate change. United Nations. https://unfccc. int/resource/docs/convkp/conveng.pdf. Accessed 9 August 2019 
UN Environment (2018) Emissions gap report 2018. United National Environment Program https://www. unenvironment.org/resources/emissions-gap-report-2018. Accessed 9 August 2019

UNFCCC (2002) Decision 11/CP.7 of the Marrakesh accord the following definitions of forests, afforestation and reforestation were adopted. United Nations framework convention on climate change. https://unfccc. int/resource/docs/cop7/13a01.pdf. Accessed 9 August 2019

van der Heijden GMF, Powers JS, Schnitzer SA (2015) Lianas reduce carbon accumulation and storage in tropical forests. PNAS 112(43):13267-13271. https://doi.org/10.1073/pnas.1504869112

Vieira S, Trumbore S, Camargo PB et al (2005) Slow growth rates of Amazonian trees: consequences for carbon cycling. Proc Natl Acad Sci U S A 102(51):18502-18507

Waring BG, Powers JS (2017) Overlooking what is underground: Root:shoot ratios and coarse root allometric equations for tropical forests. For Ecol Manag 385:10-15.

Watson J, Evans T, Venter O, Williams B, Tulloch A, Stewart C, Thompson I, Ray J, Murray K, Salazar A, Mcalpine C, Potapov P, Walston J, Robinson J, Painter M, Wilkie D, Filardi C, Laurance W, Houghton R, Lindenmayer D (2018) The exceptional value of intact forest ecosystems. Nat Ecol Evol 2:599-610. https://doi.org/10.1038/s41559-018-0490-x

Winjum JK, Brown S, Schlamadinger B (1998) Forest harvests and wood products: sources and sinks of atmospheric carbon dioxide. For Sci 44(2):272-283

Xu B, Pan Y, Plante AF, McCullough K, Birdsey R (2017) Modelling forest carbon cycle using long-term carbon stock field measurements in the Delaware River Basin. Ecosphere 8(5):e01802. https://doi.org/10.1002 /ecs2.1802

Yang F-F, Li Y-L, Zhou G-Y, Wenigmann K, Zhang D, Wenigmann M, Zhang Q-M (2010) Dynamics of coarse woody debris and decomposition rates in an old-growth forest in lower tropical China. For Ecol Manage 259:1666-1672. https://doi.org/10.1016/j.foreco.2010.01.046

Zimmerman BL, Kormos CF (2012) Prospects for sustainable logging in tropical forests. BioScience 62:479-487

Publisher's note Springer Nature remains neutral with regard to jurisdictional claims in published maps and institutional affiliations.

\section{Affiliations}

\section{Brendan Mackey ${ }^{1} \cdot$ Cyril F. Kormos $^{2} \cdot$ Heather Keith ${ }^{1,3} \cdot$ William R. Moomaw ${ }^{4} \cdot$ Richard $^{2}$ A. Houghton ${ }^{5} \cdot$ Russell A. Mittermeier $^{6} \cdot$ David Hole $^{7} \cdot$ Sonia Hugh ${ }^{1}$}

Brendan Mackey

b.mackey@griffith.edu.au

1 Griffith Climate Change Response Program, Griffith University, Gold Coast, Queensland 4221, Australia

2 Wild Heritage, 2150 Allston Way, Suite 460, Berkeley, CA 94704, USA

3 Fenner School of Environment and Society, Australian National University, Canberra, ACT 0200, Australia

4 The Fletcher School, Tufts University, 160 Packard Ave, Medford, MA 02155, USA

5 Woods Hole Research Centre, 149 Woods Hole Road, Falmouth, MA 02540-1644, USA

6 Global Wildlife Conservation, Austin, TX 78767, USA

7 Moore Centre for Science, Conservation International, 2011 Crystal Drive, Arlington, VA 22202, USA 